\title{
Wasting Mechanisms in Muscular Dystrophy
}

\author{
Jonghyun Shin, Marjan M. Tajrishi, Yuji Ogura, and Ashok Kumar ${ }^{\star}$ \\ Department of Anatomical Sciences and Neurobiology, University of Louisville School of \\ Medicine, Louisville, Kentucky 40202, USA
}

\begin{abstract}
Muscular dystrophy is a group of more than 30 different clinical genetic disorders that are characterized by progressive skeletal muscle wasting and degeneration. Primary deficiency of specific extracellular matrix, sarcoplasmic, cytoskeletal, or nuclear membrane protein results in several secondary changes such as sarcolemmal instability, calcium influx, fiber necrosis, oxidative stress, inflammatory response, breakdown of extracellular matrix, and eventually fibrosis which leads to loss of ambulance and cardiac and respiratory failure. A number of molecular processes have now been identified which hasten disease progression in human patients and animal models of muscular dystrophy. Accumulating evidence further suggests that aberrant activation of several signaling pathways aggravate pathological cascades in dystrophic muscle. Although replacement of defective gene with wild-type is paramount to cure, management of secondary pathological changes has enormous potential to improving the quality of life and extending lifespan of muscular dystrophy patients. In this article, we have reviewed major cellular and molecular mechanisms leading to muscle wasting in muscular dystrophy.
\end{abstract}

\section{Keywords}

Muscular dystrophy; NF-kappa B; Matrix metalloproteinases; osteopontin; TGF- $\beta$

\section{Introduction}

Muscular dystrophy comprises a group of genetic diseases that cause progressive degeneration of skeletal muscle fibers resulting in severe pain, disability, and eventually death (Emery, 2002). The primary cause for various forms of muscular dystrophies is the mutations in individual genes that encode a wide variety of proteins, including extracellular matrix (ECM) proteins, transmembrane and membrane-associated proteins, cytoplasmic enzymes, and nuclear matrix proteins (Blake et al., 2002; Campbell, 1995). However, the most severe forms of muscular dystrophies occur due to mutations in the components of the dystrophin-glycoprotein complex (DGC), a molecular scaffold which is localized to sarcolemma and provides mechanical stability to striated muscle (Figure 1). For example, mutations in dystrophin or any of the sarcoglycans leads to destabilization of sarcolemma (i.e. muscle membrane) and a dystrophic phenotype.

Duchenne muscular dystrophy (DMD) is one of the most prevalent forms of muscular dystrophies that results from total or partial deficiency of functional dystrophin protein (Figure 1). Dystrophin is a critical component of DGC, which links the cytoskeleton of the muscle fibers to the ECM (Hoffman et al., 1987). Dystrophin has also been suggested as an

*Corresponding author: Ashok Kumar, Ph.D. Professor and University Scholar Department of Anatomical Sciences and Neurobiology, University of Louisville School of Medicine, 500 South Preston Street, Louisville, KY 40202, USA Tel: 1-502-852-1133 Fax: 
important cytolinker that stabilizes cells by linking actin filaments, intermediate filaments, and microtubules to transmembrane complexes (Prins et al., 2009). In the absence of dystrophin, the DGC is functionally impaired and the mechanical stress associated with muscle contraction leads to sarcolemmal damage and fiber necrosis (Petrof et al., 1993; Rando, 2001). While mechanical injury and sarcolemmal defects are important triggering mechanisms promoting dystrophic phenotype, neither fully explains the onset of DMD or its progression. Studies in animal models and humans have shown that partial or complete loss of DGC proteins results in the activation of several pathological cascades which aggravate disease progression (Chakkalakal et al., 2005; Engvall and Wewer, 2003; Khurana and Davies, 2003; Rando, 2001; Spencer and Tidball, 2001).

Besides acting as a molecular scaffold serving mechanical function, DGC also has an important signaling role in striated muscle. Disruption of DGC leads to the aberrant activation of a number of signaling pathways (Acharyya et al., 2007; Bhatnagar and Kumar, 2010; Dogra et al., 2006; Kumar and Boriek, 2003; Kumar et al., 2004a). Intriguingly, many signaling pathways that have been found to be involved in pathogenesis of muscular dystrophy are activated before the onset of fiber necrosis signifying that loss of functional DGC is sufficient to disrupt physiological signaling in striated muscle (Bhatnagar and Kumar, 2010). Abnormal myogenic signaling has also been reported in other forms of muscular dystrophies that result from loss of nuclear membrane protein (e.g. lamins A/C, Emerin) or cytoplasmic enzymes (e.g. calpain-3) suggesting that signaling defects is a common pathological mechanism in all types of muscular dystrophies (Bhatnagar and Kumar, 2010). Because activation of different signaling cascades results in altered gene expression, aberrant myogenic signaling could be critical for the onset and perpetuation of pathology in muscular dystrophy.

While it is obvious that gene therapy and stem cell-based therapy would likely provide the cure for DMD and other types of muscular dystrophy (Davies and Grounds, 2007;

Goyenvalle et al., 2011), it is not yet clear when these approaches will be developed in near future to be useful for patients with muscular dystrophy. Dystrophin gene size is considerably large which has been a major impediment in the development of effective gene therapy protocols for DMD patients. Systemic delivery of the gene therapy vectors (e.g. plasmids and adeno-associated viruses) to muscles that are distributed all over the body also creates another obstacle (Goyenvalle et al., 2011). Use of antisense oligonucleotides (AON) to modulate splicing of the dystrophin gene to restore a translatable mRNA transcript has also been proposed on the basis of in vitro data. However, in vivo studies showed that the dystrophin expression was highly variable within and between muscles and there is no detectable expression of dystrophin in cardiac muscle even after repeated intravenous injections of AON (Lu et al., 2011). Premature termination codon (PTC) mutations occur in $\sim 15 \%$ of patients with DMD. It has been suggested that boys with DMD can potentially be treated by drugs that promote read-through. Aminoglycosides restore protein translation in cultured cells. However, aminoglycosides and related compounds have long-term toxic effects and initial human trials have been disappointing (Bidou et al., 2012; Finkel, 2010). Furthermore, dystrophin expressed by DMD patients could also be antigenic, which is another obstacle even after protocols for gene or stem cells delivery into muscle are developed (Goyenvalle et al., 2011). The intractable difficulty of gene and cellular therapeutics warrants the need for development of alternative strategies to preserve skeletal muscle mass in muscular dystrophy patients.

Considerable progress has been now made to understanding the pathophysiological mechanisms in muscular dystrophy. These studies have shown that indifferent of primary genetic mutations, the pathogenesis of muscular dystrophy involves several common mechanisms such as calcium influx, infiltration of muscle tissue by inflammatory immune 
cells, accretion of proinflammatory and profibrogenic cytokines, activation of various proteolytic enzymes, defective autophagy, and apoptosis in some instances (Figure 2). In this article, we have discussed the key cellular and molecular mechanisms contributing to muscle wasting in various types of muscular dystrophy with emphasis on DMD.

\section{Membrane instability and calcium influx}

Sarcolemmal instability is one of the key early events which lead to the pathological features observed at later stages of disease progression in muscular dystrophy. Abnormal calcium $\left(\mathrm{Ca}^{2+}\right)$ homeostasis has been suggested to play an important role in skeletal muscle degeneration in muscular dystrophy (Culligan and Ohlendieck, 2002). Initial studies demonstrated a large increase in $\mathrm{Ca}^{2+}$ concentration in cytosol of both resting and stimulated skeletal muscle of dystrophic mice and humans leading to the hypothesis that calcium itself can promote muscular dystrophy by inducing myofiber necrosis (Culligan and Ohlendieck, 2002; Mongini et al., 1988; Turner et al., 1988; Williams et al., 1990). More recent studies have provided evidence that $\mathrm{Ca}^{2+}$ levels are not uniformly elevated within the cytosol but this phenomenon is restricted to subsarcolemmal space (Mallouk et al., 2000). Moreover, myofibers from dystrophin-deficient $m d x$ (a mouse model of DMD) mice have been found to be more susceptible to contraction- or stress-induced calcium influx suggesting passive $\mathrm{Ca}^{2+}$ entry through physical openings of the sarcolemma as a primary mechanism (Culligan and Ohlendieck, 2002). However, direct measurements of membrane currents have shown that dystrophic myofibers have increased $\mathrm{Ca}^{2+}$ leakage across channels suggesting that $\mathrm{Ca}^{2+}$ uptake can occur through both passive and active mechanisms (Alderton and Steinhardt, 2000; Fong et al., 1990; Franco and Lansman, 1990; Hopf et al., 1996; Mallouk et al., 2000; Wang et al., 2005). Overexpression of dystrophin protein was sufficient to prevent the elevation in intracellular $\mathrm{Ca}^{2+}$ levels further suggesting a link between sarcolemmal destabilization and disruption of calcium homeostasis in dystrophin-deficient muscles (Denetclaw et al., 1994).

Studies employing muscle-specific transgenic mice over-expressing transient receptor potential canonical 3 (TRPC3) have suggested that $\mathrm{Ca}^{2+}$ itself is sufficient to induce dystrophic muscle phenotype independent of membrane instability. Overexpression of TRPC3 led to an increase in $\mathrm{Ca}^{2+}$ concentration and major phenotypes of muscular dystrophies such as myofiber degeneration and regeneration, infiltration of immune cells, and fibrosis (Millay et al., 2009). Furthermore, transgenic overexpression of a dominant negative mutant of TRPC6 in mdx or sarcoglycan-deficient $\left(\mathrm{Sgcd}^{t-}\right)$ models of muscular dystrophy showed that the inhibition of $\mathrm{Ca}^{2+}$ influx mitigates dystrophic phenotypes (Millay et al., 2009). Thus, TRPC channels appear to be the major initiators of $\mathrm{Ca}^{2+}$ influx and pathology downstream of unstable sarcolemma that characterizes many types of muscular dystrophy.

One of the important mechanisms by which elevated level of $\mathrm{Ca}^{2+}$ causes muscle wasting in muscular dystrophy is through activation of calcium-dependent proteases such as calpains which eventually lead to the degradation of muscle proteins and necrosis (Goll et al., 2003). Previous studies have shown increased calpain activities in dystrophic myofibers that can be inhibited using protease inhibitors or calcium chelators (Alderton and Steinhardt, 2000;

Nagy and Samaha, 1986). Direct evidence for the importance of calcium-activated calpain proteases in muscle degeneration came from experiments from Melissa Spencer's group (Spencer and Mellgren, 2002). Calpastatin is a specific inhibitor of $\mathrm{m}$ - and $\mu$-calpains but not calpain 3. Transgenic overexpression of calpastatin in skeletal muscle of mdx mice inhibited the activity of endogenous calpains and considerably reduced muscle necrosis at the age of 4-week (Spencer and Mellgren, 2002). These experiments suggest that calpains 
play an important role in fiber necrosis in dystrophic muscle and that inhibition of calpains can ameliorate dystrophinopathy.

$\mathrm{Ca}^{2+}$ are also important secondary messengers that trigger intracellular responses such as excitation-contraction (E-C) coupling and activation of various signaling pathways (Gailly, 2002). Therefore, abnormal $\mathrm{Ca}^{2+}$ homeostasis can adversely affect $\mathrm{E}-\mathrm{C}$ coupling and activation of various signaling pathways (Culligan and Ohlendieck, 2002). Mechanical stretch increases $\mathrm{Ca}^{2+}$ influx through stretch-activated channels which leads to activation of extracellular signal regulated kinase1/2 (ERK) and downstream proinflammatory transcription factors such as activator protein-1 (AP1) in myofibers of mdx mice. Interestingly, abnormal activation of ERK1/2 signal transduction has been observed in hearts of Lmna H222P mice, a model of Emery-Dreifuss muscular dystrophy though it is clear whether increased $\mathrm{Ca}^{2+}$ influx is the reason for their activation in this model (Muchir et al., 2007). Recently, Altamirano et al. (Altamirano et al., 2012) reported that resting $\mathrm{Ca}^{2+}$ is higher in cultured myotubes from mdx mice and it contributes to the activation of proinflammatory nuclear factor-kappa $\mathrm{B}(\mathrm{NF}-\mathrm{\kappa B})$ transcription factor and its downstream target gene -inducible nitric oxide synthase (iNOS).

Elevated levels of $\mathrm{Ca}^{2+}$ can also affect muscle pathology by modulating the activity of calcineurin/nuclear factor of activated T-cells (NFAT) pathway. In response to increase intracellular $\mathrm{Ca}^{2+}$, NFAT is dephosphorylated by the calcium- and calmodulin-dependent phosphatase calcineurin, resulting in nuclear translocation of the transcription factor (Hogan et al., 2003). Indeed, increased activation of calcineurin signal transduction pathway has been reported in skeletal muscle of mdx mice (Stupka et al., 2004; Stupka et al., 2006; Stupka et al., 2008). Intriguingly, transgenic expression of calcineurin in skeletal muscle resulted in increased nuclear localization of NFATc1, fiber type shifting towards a slower phenotype, increased levels of utrophin, and improved sarcolemmal integrity (Chakkalakal et al., 2004). Conversely, transgenic overexpression of a small peptide inhibitor for calmodulin, an upstream activator of calcineurin, represses the levels of utrophin, and exacerbates dystrophic phenotype in mdx slow-type fibers (Chakkalakal et al., 2006). It is notable that in comparison to mdx mice, serum level of calcineurin is significantly lower in DMD patients (Sundaram et al., 2007) which may account for the impairment of muscle regeneration, insufficient utrophin expression, and severe pathology in DMD patients. While published reports indicate stimulation of calcineurin/NFAT pathway as a promising therapy for DMD, the potential of negative side-effects caused by activation of calcineurin-NFAT signaling in other tissues must not be overlooked. For example, cardiac hypertrophy is known to be induced by calcineurin (Molkentin et al., 1998) and, thus, systemic stimulation of calcineurin signaling can further aggravate the incidence of heart failure in DMD patients. Moreover, it is apparent that the activation of calcineurin/NFAT pathway may benefit only select types of muscular dystrophies. Transgenic overexpression of calcineurin using a muscle-specific promoter accelerated muscle fiber loss and cardiac fibrosis and reduced cardiac ventricular shortening in $\mathrm{Sgcd}^{+-}$model of limb-girdle muscular dystrophy $2 \mathrm{~F}$ (LGMD2F). By contrast, muscle-specific deletion of calcineurin B1 (CnB1) gene reduced skeletal muscle degeneration and histopathology in these mice (Parsons et al., 2007) indicating that calcineurin activation has worsening effects in LGMD2F.

\section{Inflammatory Response}

A number of studies employing microarray technique have examined genome-wide gene expression in muscle biopsies from DMD patients (Haslett et al., 2002) and in myofibers of mdx mice (Porter et al., 2001; Porter et al., 2002; Porter et al., 2004; Porter et al., 2003b). These studies showed a higher expression of genes involved in inflammatory responses in the affected muscles (diaphragm and limb muscles) but not in the spared extraocular muscle 
(Porter et al., 2001; Porter et al., 2003b). Other independent studies have confirmed increased expression of several inflammatory molecules including cytokines (e.g. TNF-a, IL-1 $\beta$, and IL-6) and cell adhesion molecules (e.g. intracellular adhesion molecule-1) in dystrophic myofibers (Acharyya et al., 2007; Chen et al., 2005; Kumar and Boriek, 2003; Vidal et al., 2008; Wehling-Henricks et al., 2004).

Several cells involved in immune response are the major source for inflammatory cytokines in dystrophic muscle. Indeed, immune cells infiltration which precedes the onset of initial disease and persistent through later stages is now considered as a specific response that directly contributes to inflammation and muscle lesion formation and progression (Evans et al., 2009). Intense exercise in healthy muscle is associated with transient inflammation, which is a part of homeostatic process (Tidball, 1995). However, in mdx mice and patients with DMD, the immune cell infiltration associated with muscle lesions is clearly distinct from non-specific immune response that occurs in normal muscle injury (Cai et al., 2000; Gorospe et al., 1994a; Hodgetts et al., 2006; Spencer et al., 2001; Spencer and Tidball, 2001; Spencer et al., 1997; Tidball, 2005; Wehling et al., 2001). Macrophages, T cells, and neutrophils are the primary immune cell types that invade muscle cells between the ages of 2-4 weeks (Evans et al., 2009). It has been previously demonstrated that depletion of macrophages via systemic administration of a monoclonal antibody results in dramatic reduction of injured fibers in mdx mice suggesting that these cells play a major role in development of muscle lesions (Wehling et al., 2001). Activated macrophages lyse muscle cells through the production of nitric oxide (NO). Macrophages are also a major source of proinflammatory cytokines which cause muscle wasting through activation of proteolytic systems and inhibiting muscle regeneration (Evans et al., 2009; Grounds and Torrisi, 2004; Langen et al., 2001; Sharma and Anker, 2002). Furthermore, macrophages can cause phagocytosis of injured myofibers and then present antigens to $\mathrm{T}$ cells to induce their activation. In fact, T cells, mast cells, eosinophils, and neutrophils are also present in abundance and contribute to fiber wasting in dystrophic muscle (Cai et al., 2000; Gorospe et al., 1994a; Hodgetts et al., 2006).

Macrophages have two subpopulations. M1 macrophages are proinflammatory and promote muscle lysis through production of nitric oxide and inflammatory cytokines. M2 macrophages are generally anti-inflammatory which can also augment skeletal muscle regeneration through stimulating the proliferation of satellite cells (Tidball and Villalta, 2010). Initial activation of proinflammatory macrophages is mediated by inflammatory cytokines which is not influenced by muscle cells. However, at later stages, cytokines produced by muscle cells may also contribute towards prolonged activation of macrophages (Tidball and Villalta, 2010). TNF- $a$ and IFN- $\gamma$ are two inflammatory cytokines produced by both M1 macrophages and skeletal muscle cells (Javierre et al., 2010; Kumar et al., 2010; Tidball and Villalta, 2010). Increased levels of these cytokines facilitate the activation of M1 macrophages and inhibit transition from M1 to M2 phenotype. In contrast, antiinflammatory cytokines such as IL-4 and IL-10 promote activation of M2 macrophages. Intriguingly, both M1 and M2 macrophages are present in dystrophic muscle of mdx mice. Recent studies have shown that treatment of mdx mice with IL-10 improves dystrophinopathy through deactivating M1 macrophages and promoting M2 phenotype (Villalta et al., 2009; Villalta et al., 2011b). By contrast, IFN- $\gamma$ promotes dystrophic phenotype by causing fiber necrosis as well as through deactivating M2 macrophages and attenuating satellite cell proliferation (Villalta et al., 2011a). Together, these studies provide initial evidence that modulation of macrophage phenotype using cytokines can be used as a therapeutic approach to improve dystrophinopathy.

$\mathrm{CD} 8^{+} \mathrm{T}$ cells present in dystrophic muscle can directly trigger muscle cell death whereas $\mathrm{CD} 4^{+} \mathrm{T}$ cells can be an important source for inflammatory cytokines to CD8+ $\mathrm{T}$ cells and 
other immune cell types. Previous studies have shown that $\mathrm{T}$ cells can cause muscle loss by perforin-mediated cytotoxicity (Spencer et al., 1997). Genetic ablation of perforin in mdx mice considerably reduced fiber necrosis in mdx mice (Spencer et al., 1997). Moreover, antibody-mediated depletion of $\mathrm{CD} 8^{+}$or $\mathrm{CD} 4^{+} \mathrm{T}$ cells in mdx mice resulted in reduction in muscle histopathology (Spencer et al., 2001). Neutrophils also infiltrate muscle tissues at early stages in mdx mice. The role of neutrophil in dystrophinopathy has been suggested by a study by Hodgetts et al. (Hodgetts et al., 2006). Antibody-mediated depletion of neutrophils in $\mathrm{mdx}$ mice considerably reduced fiber necrosis and subsequent regeneration (Hodgetts et al., 2006). Neutrophils are the major source of superoxide production. Thus one of the possible mechanisms by which neutrophils cause muscle necrosis is through the production of superoxide (Tidball, 2005).

Mast cells have also been implicated in dystrophinopathy (Gorospe et al., 1994a; Gorospe et al., 1994b). Mast cells degranulation is commonly observed in areas surrounding injured myofibers. Degranulation of mast cells releases certain proteases such as chymase, tryptase, carboxypeptidase which can promote membrane lysis. Furthermore, release of TNF-a and histamines from mast cells granules can promote fiber necrosis via creating muscle microenvironment more proinflammatory. Indeed, cromolyn, a blocker of mast cell degranulation has been found to reduce muscle damage in mdx mice (Gorospe et al., 1994b).

Analysis of muscle biopsies from patients with DMD has also shown similar increase in various immune cells (Evans et al., 2009). These studies have shown that macrophages and $\mathrm{CD}^{+} \mathrm{T}$ cells are the major immune cells that infiltrate dystrophic muscle between age of 2-8 years (Arahata and Engel, 1988a; Arahata and Engel, 1988b; Gorospe et al., 1994b; McDouall et al., 1990). Elevated concentration of mast cells has also been reported at the age 3 years in patients with DMD compared to healthy individuals (Gorospe et al., 1994b). Although immune response in DMD patients has not been fully characterized, the presence of immune cells in dystrophic muscle of DMD patients as well as animal models has led to the hypothesis that immunosuppressive approaches would provide therapeutic benefits in DMD. However, clinical trials using broad spectrum immunosuppressant for treatment of DMD produced mixed results with no major improvement in pathology (Kirschner et al., 2010). Although the exact reasons for failure of these drugs are not clear, a few possibilities can be discussed. An apparent drawback in these studies is that the drugs used were not specifically immunosuppressant as they produce several other effects in addition to immunosuppression. For example, cyclosporine A though is an immunosuppressant is also a known inhibitor of calcineurin which is required for muscle regeneration after injury (Stupka et al., 2004). Azathioprine is another immunosuppressive drug tested in DMD patients but failed to produce therapeutic benefits (Griggs et al., 1993; Kissel et al., 1993). Since azathioprine is also a non-specific anti-mitotic, it can inhibit satellite cell proliferation and hence muscle regeneration in DMD patients. Thus, the blunt tool of immunosuppression may not be an ideal strategy for manipulating the immune system to reduce muscle wasting in muscular dystrophy (Tidball and Wehling-Henricks, 2004). More investigations are required to understand the dynamic interactions between immune system and dystrophic muscle in order to develop effective immunomodulation-based treatments for DMD.

\section{NF-KB Signaling}

Emerging evidence suggests that NF- $\mathrm{KB}$ transcription factor is one of the major mediators of muscle wasting in muscular dystrophy. The NF- $\mathrm{xB}$ family contains five members: RelA (also known as p65), RelB, c-Rel, p105/p50, and p100/p52 which make homo- and hetrodimers (Hayden and Ghosh, 2004; Li et al., 2008). Depending on the type of stimuli, the activation of NF- $\mathrm{xB}$ can occur through canonical or non-canonical signaling pathway. Canonical NF- $\kappa \mathrm{B}$ signaling involves the upstream activation of inhibitors of $\kappa \mathrm{B}$ (I $\kappa \mathrm{B}$ ) 
kinase- $\beta$ (IKK $\beta$ ) and subsequent phosphorylation and degradation of I $\mathrm{kB}$ protein. In contrast, the activation of non-canonical NF- $\kappa$ B pathway requires the activation of NF- $\kappa B$ inducing kinase (NIK) and IKKa leading to phosphorylation and proteolytic processing of p100 subunit into p52 (Hayden and Ghosh, 2004). NF- $\mathrm{kB}$ is known to regulate a number of processes including the development of immune system, inflammation, acute stress response, cellular proliferation and differentiation, and protection against cell death (Aggarwal, 2004; Hayden and Ghosh, 2004; Kumar et al., 2004b).

Although NF- $\mathrm{BB}$ is essential for cell survival, a plethora of literature now exists suggesting that activation of NF- $\mathrm{kB}$ causes skeletal muscle wasting (Li et al., 2008). Three mechanisms have been suggested by which activated NF- $\mathrm{KB}$ induces muscle loss in both physiological and pathophysiological conditions: (a) NF- $\mathrm{KB}$ augments the expression of several proteins involved in the ubiquitin-proteasome system including E3 ubiquitin ligase MuRF1, which stimulates the loss of skeletal muscle; (b) NF- $\mathrm{kB}$ also increases the expression of many proinflammatory cytokine, chemokines, cell adhesion molecules, and matrix-degrading enzymes which exacerbate skeletal muscle loss; (c) Finally, activated NF- $\kappa B$ can block the regeneration of myofibers in response to injury (reviewed in (Li et al., 2008)).

Because inflammation is a prominent pathological feature in muscular dystrophy (Chen et al., 2005; Pescatori et al., 2007; Porter et al., 2003a; Porter et al., 2002; Porter et al., 2004) and NF- $\mathrm{KB}$ is a major proinflammatory transcription factor (Aggarwal, 2004), in an earlier study, we examined activation of NF- $\kappa B$ in skeletal muscle of mdx mice. DNA-binding activity of NF- $\kappa$ B and the expression of NF- $\kappa B$-regulated inflammatory cytokines TNF- $a$ and IL- $1 \beta$ were found to be substantially upregulated in the skeletal muscle of mdx mice (Dogra et al., 2006; Kumar and Boriek, 2003). Muscle-specific activation of NF- $\kappa B$ precedes the onset of muscle degeneration in mdx mice (Kumar and Boriek, 2003). Elevated levels of activated NF- $\mathrm{\kappa B}$ have now been reported in skeletal muscle of different animal models of DMD (Acharyya et al., 2007; Durham et al., 2006; Hnia et al., 2008; Messina et al., 2006a; Siegel et al., 2009) and Emery-Dreifuss muscular dystrophy (Lammerding et al., 2004). Furthermore, increased activation of NF- $\mathrm{KB}$ has been observed in muscle biopsies of DMD patients (Acharyya et al., 2007; Chen et al., 2005; Monici et al., 2003) and inflammatory myopathies (Haslbeck et al., 2005; Macaione et al., 2007).

The role of NF- $\mathrm{kB}$ in dystrophinopathy has been elucidated by genetic and pharmacological approaches. Deletion of single allele of NF- $\kappa B$ subunit p65 (RelA) was sufficient to considerably reduce the infiltration of macrophages, fiber necrosis, and calcification in dystrophic muscle of mdx mice (Acharyya et al., 2007). Inhibition of NF- $\kappa B$ also augmented myofiber regeneration in mdx mice (Acharyya et al., 2007). These observations are consistent with other published reports demonstrating that activated NF- $\mathrm{kB}$ inhibits the differentiation of muscle progenitor cells into multinucleated myotubes ( $\mathrm{Li}$ et al., 2008). A recent study has also shown that inhibition of NF- $\mathrm{kB}$ improves the proliferation, differentiation, and transplantation of muscle-derived stem cells in dystrophic muscle (Lu et al., 2012). Furthermore, shRNA-mediated knockdown of RelA or overexpression of a dominant negative mutant of IKKa or IKK $\beta$ using adeno-associated virus (AAV) also ameliorated pathology and improved regeneration in mdx mice (Tang et al., 2010; Yang et al., 2012). Importantly, specific depletion of IKK $\beta$ in macrophages also considerably reduced the expression of inflammatory cytokines, muscle pathology, and enhanced myofiber regeneration (Acharyya et al., 2007) further suggesting that macrophages play an important role in DMD pathology possibly through increased production of NF- $\mathrm{kB}$ regulated proinflammatory cytokines in skeletal muscle microenvironment.

The activation of IKKs in NF- $\mathrm{kB}$ pathway is tightly regulated by the non-catalytic IKK $\gamma /$ NEMO (Hayden and Ghosh, 2004; Li et al., 2008). An N-terminal a-helical region of 
NEMO associates with a hexapeptide sequence within the extreme carboxyl terminus of IKK $\beta$ and IKKa, termed NEMO-binding domain (NBD). A short cell-permeable peptide spanning the IKK $\beta$ NBD disrupts the association of NEMO with IKK $\beta$, blocks NF- $\kappa B$ activation, and ameliorates responses in animal models of inflammation (May et al., 2000). NBD peptide has now been tested in animal models of DMD. The results of these studies have reliably showed that treatment with cell permeable NBD peptide reduces inflammation, fiber necrosis, and provide functional gain in both $\mathrm{mdx}$ and $\mathrm{mdx} / \mathrm{utrophin}$ double knockout mice (Acharyya et al., 2007; Delfin et al., 2011; Peterson et al., 2011; Reay et al., 2011).

While the inhibition of NF- $\mathrm{BB}$ seems to be a promising approach for treatment of DMD, it is worth mentioning that blocking NF- $\kappa \mathrm{B}$ might not be effective in all conditions. It is possible that a certain level of NF- $\kappa \mathrm{B}$ activity is required to protect myofibers from undergoing apoptosis whereas constitutive activation of NF- $\kappa \mathrm{B}$ leads to inflammation and other dystrophic features. LGMD2A is a recessive genetic disorder caused by mutations in the cysteine protease calpain-3 (Emery, 2002). Loss of functional calpain-3 leads to apoptosis in skeletal muscle of LGMD2A patients and in mice null for calpain-3 (Emery, 2002).

Calpain-3 is required for the degradation of $I \kappa B a$ protein and hence the activation of NF- $\kappa B$ and suppression of apoptosis in skeletal muscle (Baghdiguian et al., 1999; Richard et al., 2000). The pro-survival function of NF- $\kappa B$ in muscular dystrophy is not surprising because $\mathrm{NF}-\mathrm{\kappa B}$ is also known to induce the expression of several anti-apoptotic genes (Bonizzi and Karin, 2004; Kumar et al., 2004b). It has been reported that the expression of cellularFLICE inhibitory protein (c-FLIP), a NF- $\mathrm{kB}$-regulated cell survival protein, is downregulated in LGMD2A muscle biopsies (Benayoun et al., 2008). Though the reduced activity of NF- $\mathrm{kB}$ appears to be a reason for the pathogenesis of LGMD2A, it remains to be investigated whether specific activation/expression of NF- $\mathrm{kB}$ can rescue skeletal muscle pathogenesis in LGMD2A patients.

Many of the pathological effects of NF- $\kappa \mathrm{B}$ in dystrophic muscle are mediated by the canonical pathway which involves the formation of p50:p65 dimer. Recent studies have shown that non-canonical arm of NF- $\mathrm{kB}$ signaling which involve p52:RelB dimer may induce myoblast fusion and promote oxidative phenotype in differentiated skeletal muscle (Bakkar et al., 2012; Enwere et al., 2012). Activation of both canonical and non-canonical NF- $\mathrm{kB}$ signaling is regulated by cellular inhibitor of apoptosis-1 and -2 (cIAP1/2) proteins. cIAP1/2 are also E3 ubiquitin ligases (possessing both Lys63- and Lys48-ubiquitination activity) which function by ubiquitinating various adaptor proteins and kinases, targeting them for either degradation or formation of signaling scaffolds. cIAPs blocks the noncanonical branch of NF- $\kappa$ B signaling by facilitating Lys48-linked ubiquitination of NF- $\kappa B$ inducing kinase (NIK) which targets it for proteasomal degradation (Varfolomeev et al., 2007). In basal state, cIAP, NIK, TNF-receptor associate factor (TRAF) 2 and TRAF3 form a complex leading to constitutive degradation of NIK through proteasome-dependent pathway. However, in response to specific stimuli, TRAF2-TRAF3-cIAP complex is recruited to the receptor where TRAF2-mediated, Lys63-linked ubiquitination of cIAP1/2 switches its Lys48 ubiquitin ligase activity from NIK to TRAF3. The degradation of TRAF3 destabilizes the TRAF-cIAP complex allowing the accumulation of newly synthesized NIK and downstream activation of IKKa and subsequent processing of p100 into p52 (Razani et al., 2011; Vallabhapurapu et al., 2008; Zarnegar et al., 2008). Recently, Enwere et al. investigated the role of non-canonical NF- $\mathrm{kB}$ signaling in muscle pathogenesis in mdx mice (Enwere et al., 2013). Interestingly, genetic ablation of cIAP1 in mdx mice reduced muscle damage and inflammation and improved soleus muscle contractile function. In cultured $\mathrm{mdx}$ myoblasts, loss of cIAP1 leads to increased activation of both canonical and noncanonical NF- $\mathrm{kB}$ pathways leading to delayed myoblast differentiation but increased fusion (Enwere et al., 2013). These findings suggest that the inhibition of cIAP1 or the activation of the noncanonical branch of NF- $\mathrm{kB}$ may have therapeutic value for DMD patients. 


\section{Oxidative stress}

Oxidative stress is an important contributor for muscle weakness and activation of NF- $\mathrm{\kappa B}$ in muscular dystrophy (Moylan and Reid, 2007; Rando, 2002; Tidball and Wehling-Henricks, 2007). Excessive oxidative stress can produce superoxide anion, hydrogen peroxide or NO. These primary oxidative species are converted to secondary reactive oxygen species (ROS) and reactive nitrogen species (RNS), such as hydroxyl radical $(\mathrm{OH} \cdot)$ and peroxynitrite $\left(\mathrm{ONOO}^{-}\right)$. Elevated levels of secondary ROS and RNS can damage membrane lipids, structural and regulatory proteins, and DNA. Increased levels of lipid and protein oxidation have been reported in dystrophic muscle of patients with DMD (Haycock et al., 1996; Kar and Pearson, 1979; Mechler et al., 1984) and animal models of muscular dystrophy (Disatnik et al., 1998; Hauser et al., 1995; Mizuno, 1984; Terrill et al., 2013) indicating that oxidative stress could be an important regulator of muscle wasting in DMD.

One of the potential mechanisms for elevated oxidative stress in dystrophic muscle is ROSgenerating $\mathrm{NAD}(\mathrm{P}) \mathrm{H}$ oxidase complex (Nox2) in sarcolemma. It has been shown that $\mathrm{NAD}(\mathrm{P}) \mathrm{H}$ oxidase is upregulated and its inhibition prevents muscle damage in tibial anterior muscle of mdx mice (Spurney et al., 2008; Whitehead et al., 2010; Williams and Allen, 2007). Other sources for oxidative stress in dystrophic muscle include infiltrating neutrophils (which contain high amount of myeloperoxidase), mitochondria, and upregulation of inducible nitric oxide synthase (reviewed in (Lawler, 2011)). Dystrophindeficient myofibers appear to be more vulnerable to oxidative stress as previously reported (Rando et al., 1998). High levels of oxidative stress can also cause muscle-wasting by further augmenting inflammatory response and interfering with the process of muscle regeneration (Rando et al., 1998).

Several recent studies have shown that antioxidant treatments prevent muscle wasting in mdx mice not only by reducing oxidative stress but also via inhibition of NF- $\mathrm{\kappa B}$. Studies by Carlson et al. (Carlson et al., 2005) and Messina et al. (Messina et al., 2006b) showed that chronic administration of pyrrolidine dithiocarbamate (PDTC), a potent antioxidant and inhibitor of NF- $\mathrm{KB}$, considerably reduced myofiber necrosis and improved muscle strength and increased skeletal muscle mass. IRFI 042, a novel dual vitamin E-like antioxidant, inhibits activation of NF- $\kappa B$ in many cell types (Altavilla et al., 2000). Treatment of mdx mice with IRFI-042 ameliorated muscle pathology, augmented myofiber regeneration, and reduced muscle fatigue (Messina et al., 2006a). IRFI-042 also inhibited NF- $\mathrm{kB}$ and blocked expression of TNF- $a$ in myofibers of mdx mice. Treatment of mdx mice $\mathrm{N}$-acetyl cysteine (NAC), a free-radical scavenger, inhibited NF- $\mathrm{kB}$ activation and improved sarcolemmal integrity and muscle functions (Whitehead et al., 2008). Moreover, it has been demonstrated that free radical scavengers such as a-lipoic acid (ALA) and L-carnitine (L-Car) block NF$\kappa B$ activation and attenuate myopathy in mdx mice (Hnia et al., 2007).

\section{Matrix metalloproteinases}

Extracellular proteases play a pivotal role in altering local microenvironment during embryonic development and growth and tissue remodeling processes. Matrix metalloproteinases (MMPs) are a family of zinc-dependent endopeptidases that play an important role in ECM degradation, inflammation, fibrosis, and activation of latent cytokines and cell adhesion molecules in various pathological states (Page-McCaw et al., 2007). MMPs are synthesized as secreted or transmembrane proenzymes and processed to an active enzyme by the removal of an amino-terminal propeptide (Page-McCaw et al., 2007; Vu and Werb, 2000). Abnormal increase in MMP levels has been found to contribute to tissue destruction in many pathological conditions such as chronic wounds, heart failure, rheumatic arthritis, fibrotic lung disease, dilated cardiomyopathy, asthma, gastric ulcer, 
central nervous system diseases, multiple sclerosis, and cancer (Chandler et al., 1997; Hoyhtya et al., 1990; Hu et al., 2007; Page-McCaw et al., 2007; Turpeenniemi-Hujanen et al., 1985; Waubant et al., 1999). Recent studies using transgenic and knockout mouse models have further revealed that MMPs also play critical roles in many physiological processes such as development, cell migration, and release of growth factors during tissue repair, and participate in host protective mechanisms (Page-McCaw et al., 2007; Vu and Werb, 2000). Once activated, MMPs are subject to inhibition by the tissue inhibitors of metalloproteinases (TIMPs) that bind to MMPs non-covalently (Page-McCaw et al., 2007; Raffetto and Khalil, 2008; Vu and Werb, 2000).

Although several MMPs exist in skeletal muscle, so far the expression of only MMP-2 (gelatinase A) and MMP-9 (gelatinase B) has been studied in detail in skeletal muscle in physiological and pathophysiological conditions (Allen et al., 1999; Choi and Dalakas, 2000; Kieseier et al., 2001; Koskinen et al., 2000; Koskinen et al., 2001). Increased expression of MMPs has also been implicated in the pathogenesis of inflammatory myopathies (Choi and Dalakas, 2000; Kieseier et al., 2001; Pearson and Young, 1993; Schoser et al., 2002). Roma et al. (Roma et al., 2004) measured the protein levels of MMP-9, myosin heavy chain, utrophin, and $\beta$-dystroglycan in relation to the intensity of necrosis-regeneration at different age points in mdx mice. It was observed that the levels of MMP-9 started increasing at around 10 days and peaked between 25 days and 2 months. During this period, the protein levels (but not mRNA) of utrophin and $\beta$-dystroglycan were significantly reduced in mdx mice indicating post-translational modification of structural proteins in the myofibers of mdx mice (Roma et al., 2004). Interestingly, it has been recently discovered that $\beta$-dystroglycan is a target of MMP-9, resulting characteristic $30 \mathrm{kDa}$ fragment of $\beta$-dystroglycan (Michaluk et al., 2007; Zhong et al., 2006). The $30 \mathrm{kDa}$ fragment of beta-dystroglycan has also been found to be increased in sarcoglycanopathy and DMD further suggesting that proteolysis of $\beta$-dystroglycan (possibly due to enhanced activation of MMP-9) disrupts the link between the ECM and cell membrane and contributes to skeletal muscle degeneration (Matsumura et al., 2005).

Studies from our and other groups have shown that the expression of several MMPs is deregulated in skeletal and cardiac muscle of animal models of DMD (Dahiya et al., 2011a; Delfin et al., 2012; Hnia et al., 2008; Kherif et al., 1999; Kumar et al., 2010; Li et al., 2009; Miyazaki et al., 2011). Analysis of mRNA samples revealed that in addition to MMP-2 and MMP-9, the expression of other MMPs such as MMP-3, -8, -10, -12, -13, -14, and -15 is also increased in gastrocnemius muscle of mdx mice (Kumar et al., 2010). Systematic administration of batimastat, a broad spectrum inhibitor of MMPs, in mdx mice reduced several pathological features such as inflammation, fiber necrosis, and fibrosis and improved diaphragm contractile function providing initial evidence that MMPs contribute to muscle wasting in mdx mice. Interestingly, the inhibition of MMPs also reduced the activation of MAPKs and AP-1 transcription factor and improved the levels of $\beta$-dystroglycan and neuronal nitric oxide synthase (nNOS) in dystrophic muscle (Kumar et al., 2010).

Doxycycline as well as other tetracycline derivatives have been shown to non-specifically inhibit the activity of various proteases especially MMPs. In a recent study, Girgenrath et al. have demonstrated that treatment with doxycycline or minocycline improves post-natal growth, delays the onset of hind-limb paralysis, and increases lifespan of the laminin-a2null mice (a model of congenital muscular dystrophy) from approximately 32 days to 70 days (Girgenrath et al., 2009). Similarly, doxycycline has been found to be effective in reducing the pathogenesis in a mouse model of oculopharyngeal muscular dystrophy (Davies et al., 2005) and in mdx mouse (Pereira et al., 2012). 
Among other MMPs, MMP-9 (gelatinase B) is one of the major regulators of muscle pathology in DMD. Interestingly, MMP-9 regulates its own expression through a positive feed-back mechanism that involves the activation of NF- $\mathrm{kB}$ in dystrophic muscle of mdx mice (Li et al., 2009). Genetic ablation of MMP-9 in mdx mice dramatically reduced levels of serum creatine kinase, infiltrating macrophages, fiber necrosis, and improved regeneration of myofibers in 8-week old mdx mice (Li et al., 2009). Ablation of MMP-9 also reduced myopathy and cardiomyopathy in 1-year old mdx mice (Dahiya et al., 2011a; Dahiya et al., 2011b). The role of MMP-9 in pathogenesis of DMD is further supported by a recent clinical study in patients with DMD (Nadarajah et al., 2011). This study showed that levels of MMP-9 were significantly higher in sera of DMD patients compared to healthy controls. MMP-9 levels were further increased in older, nonambulant patients, compared to ambulant patients suggesting that MMP-9 is linked to the disease progression in DMD. Although a small cohort (63 DMD patients) was employed, these initial findings suggest that MMP-9 can also be used as a potential biomarker for DMD disease progression (Nadarajah et al., 2011). Similar to MMP-9, levels of MMP-2 (gelatinase A) are also increased in dystrophic muscle of mdx mice (Kherif et al., 1999; Li et al., 2009). Miyazaki et al. have recently reported that genetic deletion of MMP-2 in mdx mice inhibits fiber growth and angiogenesis in skeletal muscle suggesting that this MMP may be a positive regulator of growth in regenerating fibers of mdx mice (Miyazaki et al., 2011).

Although the exact mechanisms by which MMPs contribute to disease progression in DMD remain less understood, increased expression of MMPs in skeletal muscle microenvironment may cause breakdown of the components of cytoskeleton-ECM network leading to sarcolemmal damage and fiber necrosis. Indeed, collagen IV (a major component of the basement membrane) and $\beta$-dystroglycan (an important protein of DGC) have already been validated as the direct targets of MMP-mediated proteolysis (Matsumura et al., 2005; Michaluk et al., 2007; Page-McCaw et al., 2007; Vu and Werb, 2000; Zhong et al., 2006). Enhanced activity of MMPs can augment expression or proteolytic activation of various latent inflammatory cytokines, chemokines, and growth factors leading to inflammatory response and fibrosis in skeletal muscle (Page-McCaw et al., 2007) which is also supported by the studies in mdx mice (Dahiya et al., 2011a; Dahiya et al., 2011b; Kumar et al., 2010). Finally, elevated levels of MMPs may interfere with the process of muscle regeneration in dystrophic muscle (Kumar et al., 2010; Li et al., 2009).

\section{Osteopontin}

Osteopontin (OPN), also known as early T-cell activation-1, was originally discovered as an inducible marker of transformation of epithelial cells. It is a secreted, integrin-binding matrix phosphorylated glycoprotein, involved in a number of cellular functions including cell adhesion and migration, inflammation, angiogenesis, tissue remodeling and tumor development (Wang and Denhardt, 2008). Recently, Vetrone et al. demonstrated that muscle cells and a subpopulation of T cells expressing V $\beta 8.1 / 8.2 \mathrm{TCR}$ are the major sources for OPN in mdx mice (Vetrone et al., 2009). The levels of OPN are increased both in dystrophic muscle and serum of mdx mice. Furthermore, abundance of OPN is also considerably increased in muscle biopsies from DMD patients. OPN is an important regulator of immune response and fibrosis in $\mathrm{mdx}$ mice. Ablation of OPN in $\mathrm{mdx}$ by genetic method led to reduced infiltration of neutrophils and NKT-like cells but increased the concentration of Treg cells in dystrophic muscle. In contrast, the levels of macrophages remained unaffected in muscles of OPN and mdx double mutant mice (DMM). Furthermore, accumulation of fibrotic tissue was considerably reduced in diaphragm and heart of DMM mice compared to $\mathrm{mdx}$ mice. Since OPN augments the levels of profibrogenic cytokine, TGF- $\beta$, reduced fibrosis could be attributed to the diminished levels of TGF- $\beta$ in skeletal muscle of DMM mice (Vetrone et al., 2009). 
Published reports suggest that OPN can induce the expression of a number of inflammatory molecules including MMP-9 in some cell types (Chen et al., 2009; Rangaswami et al., 2004). We investigated whether this relationship also exists in the context of muscular dystrophy. Systematic administration of OPN enhanced the expression of MMP-9 in normal mice whereas antibody-mediated neutralization of OPN reduced the levels of MMP-9 in myofibers of mdx mice demonstrating a cooperative interaction between these two molecules in pathogenesis of mdx mice (Dahiya et al., 2011b). It is noteworthy that while the inhibition of MMP-9 reduces severity of disease progression in animal models of many tissue degenerative disorders, there is still no clinically approved molecules that specifically block the activity of MMP-9. Broad spectrum MMP inhibitory drugs developed earlier failed in various clinical trials due to a musculoskeletal syndrome (41). Although more specific inhibitors of MMPs are under development, a potential alternative approach to block MMP-9 activity could be via targeting molecules, such as OPN, which induce expression of MMP-9 in muscular dystrophy and other diseases.

\section{Transforming growth factor- $\beta$}

Fibrosis is a pathogenic factor characterized by chronic inflammation with persistent production of profibrotic cytokines and excessive deposition of ECM proteins, including collagens and fibronectin which can impair tissue function (Mann et al., 2011). Fibrosis is also major pathological feature in muscular dystrophy which progressively deteriorates locomotor capacity, posture maintenance, and the vital function of cardiac and respiratory muscles (Bernasconi et al., 1995). Progressive fibrosis is also observed in diaphragm of the $m d x$ mice which recapitulates clinical signs of DMD patients (Stedman et al., 1991). A recent study in DMD patients has shown that endomysial fibrosis is the only pathological feature among fiber atrophy, hyper-contracted fibers, necrotic fibers, endomysial and perimysial fibrosis, and fatty degeneration that significantly correlates with poor motor outcome assessed by muscle strength at 10 years and at the age of ambulation loss (Desguerre et al., 2009). Fibrosis can disrupt muscle tissue function through hindering nutritional support to myofibers. It is also a major barrier for stem-cell based therapies as it can considerably reduce the proliferation and differentiation of implanted cells (Davies and Grounds, 2007; Goyenvalle et al., 2011).

The members of TGF- $\beta$ superfamily cytokines play a key role in pathogenesis in variety of fibrotic disorders including muscular dystrophy (Burks and Cohn, 2011). Among them, TGF- $\beta 1$ has been found to be a major cytokine that promotes fibrosis (Gosselin et al., 2004) by augmenting synthesis of collagen, growth and differentiation of fibroblasts, and reducing the expression of matrix degrading proteases (Border and Noble, 1994; Ignotz and Massague, 1986). TGF- $\beta$ induces cellular signaling via binding to three cell surface receptors. Type I (T $\beta R 1$ ) and type II (T $\beta$ RII) form hetrodimers and are signaling receptors whereas type III (T $\beta$ RIII) is a proteoglycan that regulates access of TGF- $\beta$ to signaling receptors (Akhurst and Hata, 2012). Binding of TGF- $\beta$ to T $\beta$ RII subunit leads to the phosphorylation and activation of T $\beta R I$. Activated T $\beta R I$ subsequently phosphorylates downstream smad proteins leading to translocation of smad complex into nucleus where they bind to DNA in a sequences-specific manner and regulate transcription of many target genes (Akhurst and Hata, 2012).

TGF- $\beta$ can be produced by many cell types including myofibers, fibroblasts, and infiltrating immune cells in dystrophic muscles. Several studies have shown that the TGF- $\beta 1$ levels are increased in muscle tissues of human DMD (Yamazaki et al., 1994) in animal models of DMD, LGMD2B, and congenital muscular dystrophy (Onofre-Oliveira et al., 2012). Expression of TGF- $\beta$ and latent TGF- $\beta$ binding protein in dystrophic muscles verified by immunostaining indicates that TGF- $\beta$ may act as a mediator to enhance synthesis and 
accumulation of ECM proteins (Yamazaki et al., 1994) thus contributing to endomysial fibrosis. In addition to an increase in amounts of TGF- $\beta$, increased phosphorylation of smad $2 / 3$ proteins, an indicator of TGF- $\beta$ signaling, has been observed in myofibers of $\mathrm{mdx}$ mice (Cohn et al., 2007). It has been proposed that fiber necrosis or injury in muscular dystrophy leads to TGF- $\beta$ signaling, which promotes fibrosis at the cost of regeneration by satellite cells (Li et al., 2004). Indeed, TGF- $\beta$ can convert myoblasts into fibroblasts suggesting that even though satellite cells are activated, they differentiate into noncontractile tissue (Li et al., 2004).

Fibrinogen is a soluble acute phase protein that is released into the blood in response to stress. It has been reported that fibrinogen accumulation and deposition of collagen show good correlation in dystrophic muscle of mdx mice and DMD patients (Vidal et al., 2008). Genetic ablation of fibrinogen or its pharmacological inhibition using ancrod, an established defibrinogenating agent considerably reduced fibrosis in $m d x$ diaphragms of 2.5- and 6.5month-old mdx mice. Interestingly, fibrinogen depletion for 6 months in $m d x$ mice also reduced the expression of TGF- $\beta$, phospho-Smad2 staining, and some target proteins such as collagen I and TIMP-1. These findings suggest that fibrinogen promotes fibrosis by increasing TGF- $\beta$ expression in $m d x$ diaphragm (Vidal et al., 2008). Recently, Ester et al. reported that TGF- $\beta$ induces fibrosis through augmenting the expression of microribonucleic acid (miR)-21 in dystrophic muscle of mdx mice (Ardite et al., 2012). The expression of miR21 was highly induced and associated with fibrosis in skeletal muscle of mdx mice and in muscle biopsies of DMD patients. Interestingly, inhibition of miR-21 reversed fibrosis in hind limb muscle of 24-month old mdx mice. Consistently, overexpression of miR-21 was sufficient to further induce fibrosis in dystrophic muscle of 3-month old mdx mice. Furthermore, it has been found that urokinase-type plasminogen activator (uPA)/plasmindependent mechanisms lead to proteolytic activation of TGF- $\beta$ in dystrophic muscle (Ardite et al., 2012).

Studies using pharmacological inhibitors of TGF- $\beta$ signaling such as losartan or halofuginone in mdx mice have shown that these compounds reduce the phosphorylation of smad2/3 proteins and collagen deposition in diaphragm, limb, and cardiac muscles (Cohn et al., 2007; Turgeman et al., 2008). However, it is notable that TGF- $\beta$ may have both beneficial and deleterious effects depending on a particular disease state, composition of ECM, or costimulatory factors. Periostin (Postn) is a secreted ECM protein which is induced by TGF- $\beta$ and affects downstream signaling. The levels of periostin are increased in both muscle tissues and in serum of $\delta$-sarcoglycan-deficient $\left(\mathrm{Sgcd}^{-/-}\right)$mice and in muscle biopsies from patients with DMD. Deletion of Postn gene in $\mathrm{Sgcd}^{-/-}$background reduced fibrosis and improved myofiber regeneration (Lorts et al., 2012). The levels of TGF- $\beta$ and phosphorylation of $\operatorname{smad} 2 / 3$ proteins were up-regulated in myofibers of $\mathrm{Sgcd}^{-/-} \mathrm{Postn}^{-/-}$mice. Interestingly, neutralization of TGF- $\beta$ using a monoclonal antibody worsened dystrophic phenotype. Further analysis showed TGF- $\beta$ neutralization increased muscle regeneration in $\mathrm{Sgcd}^{-{ }_{-}-}$mice but inhibited regeneration in $\mathrm{Sgcd}^{-{ }_{-}} \mathrm{Postn}^{-{ }_{-}}$mice suggesting that in the absence of Postn, TGF- $\beta$ signaling is altered to enhance regeneration without an increase in tissue fibrosis (Lorts et al., 2012).

\section{Myostatin}

Myostatin is another member of TGF- $\beta$ superfamily cytokines which negatively regulate skeletal muscle mass and size (Grobet et al., 1997; Lee and McPherron, 2001). Since neutralizing myostatin increases muscle growth and development, it has been suggested as a therapeutic target for muscular dystrophy. The role of myostatin in pathogenesis of muscular dystrophy has been supported by the findings that antibody-mediated neutralization or genetic ablation of myostatin in mdx mice led to improved muscle mass and strength and 
reduced leukocyte infiltration and fibrosis in dystrophic muscle (Bogdanovich et al., 2002;

Wagner et al., 2002). Furthermore, treatment with myostatin neutralizing antibody increased fiber size and muscle mass and absolute force in the $\mathrm{Sgcg}^{-/-}$mice (Bogdanovich et al., 2008). Interfering with expression of myostatin by axon skipping led to an increase in levels of Myf5 and myogenin in primary myoblasts prepared from healthy individuals or patients with DMD (Kemaladewi et al., 2011) suggesting that inhibition of myostatin leads to increased proliferation and differentiation of myoblasts. This notion is supported by the findings that myostatin negatively regulates the proliferation and differentiation of cultured satellite cells (McCroskery et al., 2003; Thomas et al., 2000). Intriguingly, Lee et al. (Lee et al., 2012) showed that genetic ablation or pharmacological blocking of myostatin activintype II receptor B (ACVR2B) increased number and size of muscle fibers in satellite celldeficient mice. Certainly, more investigations are required to further understand the mechanisms by which myostatin blockade prevents muscle wasting in muscular dystrophy.

\section{Apoptosis}

Among other mechanisms, apoptosis has been proposed to be an important contributor of muscle wasting in congenital muscular dystrophy, oculopharyngeal muscular dystrophy (OPMD), and Bethlem myopathy but not in DMD (Miller and Girgenrath, 2006). Several recent studies have used genetic and pharmacological interventions to assess the role of apoptotic pathways in pathogenesis of various types of muscular dystrophies. Merosindeficient congenital muscular dystrophy type 1A (MDC1A) is caused by autosomal recessive mutations in human LAMA2 gene. Muscle biopsies of MDC1A patients show histological signs of extensive apoptosis (Miller and Girgenrath, 2006). Inhibition of apoptosis through mitochondrial pathway ameliorated pathology and almost doubled the lifespan of Lamm2-deficient mice. Muscle-specific overexpression of apoptosis inhibitor Bcl-2 protein or targeted deletion of apoptosis inducer BAX, reduced the severity of the disease and extended mouse lifespan suggesting that apoptosis is an important pathological event in MDC1A (Dominov et al., 2005; Girgenrath et al., 2004). In cultured muscle cells, disruption of binding of laminin-a 2 to a-dystroglycan leads to activation of apoptosis through inhibition of Akt signaling thus providing a potential mechanism for induction of apoptotic pathways in MDC1A (Langenbach and Rando, 2002). Although death of myofibers primarily occurs through necrosis, apoptotic myonuclei have also been reported in both mouse models and human DMD patients (Tews, 2005; Tidball et al., 1995). However, transgenic overexpression ARC (apoptosis repressor with caspase recruitment domain) or Bcl-2 did not improve muscle pathology in mdx mice (Abmayr et al., 2004; Dominov et al., 2005) suggesting that mitochondrial pathways are not involved in the induction of apoptosis or apoptosis is not a significant contributor in pathogenesis of DMD. It is noteworthy that Akt signaling is activated above the basal level in myofibers of mdx mice which might be protecting them from undergoing apoptosis (Dogra et al., 2006; Peter and Crosbie, 2006). Indeed, increased muscle regeneration, hypertrophy, and contractile function and decreased sarcolemmal fragility has been observed in transgenic mdx mice overexpressing Akt suggesting that activation of Akt is beneficial in DMD (Blaauw et al., 2008; Peter et al., 2009). Targeted inhibition of Akt will provide evidence whether the activation of Akt protects myofiber apoptosis in DMD models.

Skeletal muscle of Col6a1-knockout mice (a model for Bethlem myopathy and ullrich congenital muscular dystrophy) show increased number of apoptotic nuclei and loss of mitochondrial function. When these mice were treated with cyclosporine A (which inhibits opening of mitochondrial permeability transition pore), disease progression was attenuated indicating that mitochondrial-mediated apoptosis is also an important contributor of disease progression in collagen VI-related muscular dystrophy (Irwin et al., 2003). Furthermore, pharmacological inhibition of apoptosis using doxycycline provided beneficial effects in a 
mouse model of OPMD (Davies et al., 2005). Taken together, these results suggest that apoptosis is an important contributor of muscle wasting in many types of muscular dystrophy if not in all.

\section{Autophagy}

Autophagy is an important homeostasis mechanism which is critical for clearing dysfunctional organelles and in preventing tissue damage (Sandri, 2010). In autophagy, a double membrane vesicle structure known as autophagosome sequesters a portion of cytoplasm including misfolded proteins and damaged organelles and fuses with lysosome where the contents of the vesicles are degraded. Accumulating evidence suggests that a certain basal level of autophagy is required for the maintenance of muscle mass whereas excessive autophagosome formation observed in conditions of starvation and denervation leads to muscle wasting (Mammucari et al., 2007; Masiero et al., 2009; Sandri, 2010; Sandri et al., 2004; Zhao et al., 2007). Akt signaling is an important regulator of autophagy in skeletal muscle. Activation of Akt inhibits autophagy through suppressing the activity of FOXO family transcription factors (Sandri, 2008). Recently, the role of autophagy in pathogenesis of muscular dystrophy has been investigated using multiple approaches. Autophagy has been found to be severely impaired in muscle biopsies from patients with DMD and in mdx mice with concomitant accumulation of damaged organelles (De Palma et al., 2012). The activation Akt-mTOR signaling observed in myofibers of mdx mice appears to be the major reason for attenuated autophagy. Notably, reactivation of autophagy by feeding low-protein diet improved muscle strength and various pathological features including fiber necrosis, pathological hypertrophy, and fibrosis in mdx mice (De Palma et al., 2012).

Pauly et al. have also provided evidence that activation of autophagy improves dystrophinopathy in mdx mice (Pauly et al., 2012). Pharmacological activation of AMPactivated protein kinase (AMPK), using AMPK agonist, AICAR (5-aminoimidazole-4carboxamide-1- $\beta$-d-ribofuranoside) led to improvements in $\mathrm{mdx}$ diaphragm histopathology and in maximal force-generating capacity (Pauly et al., 2012). Similar to DMD, defective autophagy has also been observed in muscle of Bethlem myopathy or Ullrich congenital muscular dystrophy patients and Col6a1-knockout mice (Grumati et al., 2010). Forced activation of autophagy improved myofiber survival and ameliorated the dystrophic phenotype of Col6a1-deficinet mice (Grumati et al., 2010). These findings suggest that pharmacological activation of autophagy pathways may be a useful approach for treatment of muscular dystrophy patients.

While activation of autophagy improved pathogenesis in models of DMD and Bethlem myopathy, the same interventions can produce deleterious effects in other types of muscular dystrophy. In contrast to DMD and Bethlem myopathy, the expression of autophagy-related genes has been found to be highly upregulated in muscle of MDC1A patient and Lamm2deficient mouse model (Carmignac et al., 2011). Inhibition of autophagy through systemic injection of 3-methyladenine reduced many dystrophic features such as muscle fibrosis, atrophy, apoptosis, and increased muscle regeneration and muscle mass in Lamm2-deficient mice. This treatment also improved lifespan and locomotive behavior of Lamm2-deficient mice (Carmignac et al., 2011). It is notable that in mdx and Col6al-deficinet mice, autophagy is inhibited below the basal levels and hence its activation improved muscle pathology. By contrast, in MDC1A model, it is highly activated which might be causing muscle wasting similar to its role in atrophy conditions. These findings further support the notion that a certain level of autophagy is required for clearing of damaged organelles whereas its hyperactivation induces loss of muscle mass. 


\section{Conclusions}

Evidence presented here clearly suggests that multiple interacting molecular processes occur in dystrophic muscle as it transitions from normal appearance and function at birth to dramatic loss in mass and dysfunctional state. Several molecules have now been identified in creating an unfavorable environment for muscle regeneration and promoting muscle wasting and fibrosis. Future efforts should focus on cross-talk between various molecular processes that underlie disease progression and place them in order of their activation. What parameter of muscle pathology is affected by the activation or inhibition of a specific molecular pathway should also be clearly defined. There is also a need to determine to what extent the pathogenic symptoms can be improved by regulation of a specific molecule? Although modulation of the activities of some of the involved molecular processes has been found to be beneficial in mouse models, it did not restore full function. It will be of interest to determine whether simultaneous intonation of multiple pathological pathways using pharmacological drugs can be more effective in improving muscle pathology and whether long-term studies in higher organisms such as golden retriever muscular dystrophy model will prove successful. Furthermore, it is critical to determine at what stage of disease progression, systemic intervention of a specific pathway via drug therapy will be most effective.

While offering great clinical potential for treatment of muscular dystrophies, it should be taken into consideration that continued inhibition/activation of some of the involved pathways in vivo could also be detrimental. This is because many of these pathways play an essential role in normal homeostasis, including development and functioning of immune system and cellular proliferation, self-renewal, and survival. The balance between therapeutic benefits and potential disruption of normal cellular function will be one of the most important challenges in future clinical studies. Nevertheless, research in the past couple of decades has clearly suggested that proper regulation of the activity of certain molecular processes is an important approach to attenuating muscle wasting in muscular dystrophy.

\section{Acknowledgments}

This work was supported by a Muscular Dystrophy Association, USA grant to NIH grants R01AR059810 and RO1AG029623 to A.K. We apologize to those authors whose work could not be cited due to space limitations or our oversight.

\section{Abbreviations}

$\begin{array}{ll}\text { CMD } & \text { congenital muscular dystrophy } \\ \text { DGC } & \text { dystrophin glycoprotein complex } \\ \text { DMD } & \text { Duchenne muscular dystrophy } \\ \text { ECM } & \text { extracellular matrix } \\ \text { IKK } & \text { inhibitor of I kappa B kinase a } \\ \text { LGMD } & \text { limb-girdle muscular dystrophy } \\ \text { MAPK } & \text { mitogen-activated protein kinase } \\ \text { NF-xB } & \text { nuclear factor-kappa B } \\ \text { MMPs } & \text { matrix metalloproteinases } \\ \text { MuRF1 } & \text { muscle RING-finger protein-1 }\end{array}$




$\begin{array}{ll}\text { NIK } & \text { NF- } \kappa B \text {-inducing kinase } \\ \text { NO } & \text { nitric oxide } \\ \text { RNS } & \text { reactive nitrogen species } \\ \text { ROS } & \text { reactive oxygen species } \\ \text { TGF- } \beta & \text { transforming growth factor- } \beta \\ \text { TRPC } & \text { transient receptor potential canonical }\end{array}$

\section{References}

Abmayr S, Crawford RW, Chamberlain JS. Characterization of ARC, apoptosis repressor interacting with CARD, in normal and dystrophin-deficient skeletal muscle. Hum Mol Genet. 2004; 13:213221. [PubMed: 14645204]

Acharyya S, Villalta SA, Bakkar N, Bupha-Intr T, Janssen PM, Carathers M, Li ZW, Beg AA, Ghosh S, Sahenk Z, Weinstein M, Gardner KL, Rafael-Fortney JA, Karin M, Tidball JG, Baldwin AS, Guttridge DC. Interplay of IKK/NF-kappaB signaling in macrophages and myofibers promotes muscle degeneration in Duchenne muscular dystrophy. J Clin Invest. 2007; 117:889-901. [PubMed: 17380205]

Aggarwal BB. Nuclear factor-kappaB: the enemy within. Cancer Cell. 2004; 6:203-208. [PubMed: 15380510]

Akhurst RJ, Hata A. Targeting the TGFbeta signalling pathway in disease. Nat Rev Drug Discov. 2012; 11:790-811. [PubMed: 23000686]

Alderton JM, Steinhardt RA. Calcium influx through calcium leak channels is responsible for the elevated levels of calcium-dependent proteolysis in dystrophic myotubes. J Biol Chem. 2000; 275:9452-9460. [PubMed: 10734092]

Allen DL, Roy RR, Edgerton VR. Myonuclear domains in muscle adaptation and disease. Muscle Nerve. 1999; 22:1350-1360. [PubMed: 10487900]

Altamirano F, Lopez JR, Henriquez C, Molinski T, Allen PD, Jaimovich E. Increased resting intracellular calcium modulates NF-kappaB-dependent inducible nitric-oxide synthase gene expression in dystrophic mdx skeletal myotubes. J Biol Chem. 2012; 287:20876-20887. [PubMed: 22549782]

Altavilla D, Deodato B, Campo GM, Arlotta M, Miano M, Squadrito G, Saitta A, Cucinotta D, Ceccarelli S, Ferlito M, Tringali M, Minutoli L, Caputi AP, Squadrito F. IRFI 042, a novel dual vitamin E-like antioxidant, inhibits activation of nuclear factor-kappaB and reduces the inflammatory response in myocardial ischemia-reperfusion injury. Cardiovasc Res. 2000; 47:515528. [PubMed: 10963724]

Arahata K, Engel AG. Monoclonal antibody analysis of mononuclear cells in myopathies. IV: Cellmediated cytotoxicity and muscle fiber necrosis. Ann Neurol. 1988a; 23:168-173. [PubMed: 3288082]

Arahata K, Engel AG. Monoclonal antibody analysis of mononuclear cells in myopathies. V: Identification and quantitation of T8+ cytotoxic and T8+ suppressor cells. Ann Neurol. 1988b; 23:493-499. [PubMed: 2968776]

Ardite E, Perdiguero E, Vidal B, Gutarra S, Serrano AL, Munoz-Canoves P. PAI-1-regulated miR-21 defines a novel age-associated fibrogenic pathway in muscular dystrophy. J Cell Biol. 2012; 196:163-175. [PubMed: 22213800]

Baghdiguian S, Martin M, Richard I, Pons F, Astier C, Bourg N, Hay RT, Chemaly R, Halaby G, Loiselet J, Anderson LV, Lopez de Munain A, Fardeau M, Mangeat P, Beckmann JS, Lefranc G. Calpain 3 deficiency is associated with myonuclear apoptosis and profound perturbation of the IkappaB alpha/NF-kappaB pathway in limb-girdle muscular dystrophy type 2A. Nat Med. 1999; 5:503-511. [PubMed: 10229226] 
Bakkar N, Ladner K, Canan BD, Liyanarachchi S, Bal NC, Pant M, Periasamy M, Li Q, Janssen PM, Guttridge DC. IKKalpha and alternative NF-kappaB regulate PGC-1beta to promote oxidative muscle metabolism. J Cell Biol. 2012; 196:497-511. [PubMed: 22351927]

Benayoun B, Baghdiguian S, Lajmanovich A, Bartoli M, Daniele N, Gicquel E, Bourg N, Raynaud F, Pasquier MA, Suel L, Lochmuller H, Lefranc G, Richard I. NF-kappaB-dependent expression of the antiapoptotic factor c-FLIP is regulated by calpain 3, the protein involved in limb-girdle muscular dystrophy type 2A. FASEB J. 2008; 22:1521-1529. [PubMed: 18073330]

Bernasconi P, Torchiana E, Confalonieri P, Brugnoni R, Barresi R, Mora M, Cornelio F, Morandi L, Mantegazza R. Expression of transforming growth factor-beta 1 in dystrophic patient muscles correlates with fibrosis. Pathogenetic role of a fibrogenic cytokine. J Clin Invest. 1995; 96:11371144. [PubMed: 7635950]

Bhatnagar S, Kumar A. Therapeutic targeting of signaling pathways in muscular dystrophy. J Mol Med. 2010; 88:155-166. [PubMed: 19816663]

Bidou L, Allamand V, Rousset JP, Namy O. Sense from nonsense: therapies for premature stop codon diseases. Trends Mol Med. 2012; 18:679-688. [PubMed: 23083810]

Blaauw B, Mammucari C, Toniolo L, Agatea L, Abraham R, Sandri M, Reggiani C, Schiaffino S. Akt activation prevents the force drop induced by eccentric contractions in dystrophin-deficient skeletal muscle. Hum Mol Genet. 2008; 17:3686-3696. [PubMed: 18753145]

Blake DJ, Weir A, Newey SE, Davies KE. Function and genetics of dystrophin and dystrophin-related proteins in muscle. Physiol Rev. 2002; 82:291-329. [PubMed: 11917091]

Bogdanovich S, Krag TO, Barton ER, Morris LD, Whittemore LA, Ahima RS, Khurana TS. Functional improvement of dystrophic muscle by myostatin blockade. Nature. 2002; 420:418-421. [PubMed: 12459784]

Bogdanovich S, McNally EM, Khurana TS. Myostatin blockade improves function but not histopathology in a murine model of limb-girdle muscular dystrophy 2C. Muscle Nerve. 2008; 37:308-316. [PubMed: 18041051]

Bonizzi G, Karin M. The two NF-kappaB activation pathways and their role in innate and adaptive immunity. Trends Immunol. 2004; 25:280-288. [PubMed: 15145317]

Border WA, Noble NA. Transforming growth factor beta in tissue fibrosis. N Engl J Med. 1994; 331:1286-1292. [PubMed: 7935686]

Burks TN, Cohn RD. Role of TGF-beta signaling in inherited and acquired myopathies. Skelet Muscle. 2011; 1:19. [PubMed: 21798096]

Cai B, Spencer MJ, Nakamura G, Tseng-Ong L, Tidball JG. Eosinophilia of dystrophin-deficient muscle is promoted by perforin-mediated cytotoxicity by T cell effectors. Am J Pathol. 2000; 156:1789-1796. [PubMed: 10793090]

Campbell KP. Three muscular dystrophies: loss of cytoskeleton-extracellular matrix linkage. Cell. 1995; 80:675-679. [PubMed: 7889563]

Carlson CG, Samadi A, Siegel A. Chronic treatment with agents that stabilize cytosolic IkappaB-alpha enhances survival and improves resting membrane potential in MDX muscle fibers subjected to chronic passive stretch. Neurobiol Dis. 2005; 20:719-730. [PubMed: 15955706]

Carmignac V, Svensson M, Korner Z, Elowsson L, Matsumura C, Gawlik KI, Allamand V, Durbeej M. Autophagy is increased in laminin alpha2 chain-deficient muscle and its inhibition improves muscle morphology in a mouse model of MDC1A. Hum Mol Genet. 2011; 20:4891-4902. [PubMed: 21920942]

Chakkalakal JV, Harrison MA, Carbonetto S, Chin E, Michel RN, Jasmin BJ. Stimulation of calcineurin signaling attenuates the dystrophic pathology in mdx mice. Hum Mol Genet. 2004; 13:379-388. [PubMed: 14681302]

Chakkalakal JV, Michel SA, Chin ER, Michel RN, Jasmin BJ. Targeted inhibition of Ca2+ / calmodulin signaling exacerbates the dystrophic phenotype in mdx mouse muscle. Hum Mol Genet. 2006; 15:1423-1435. [PubMed: 16551657]

Chakkalakal JV, Thompson J, Parks RJ, Jasmin BJ. Molecular, cellular, and pharmacological therapies for Duchenne/Becker muscular dystrophies. FASEB J. 2005; 19:880-891. [PubMed: 15923398] 
Chandler S, Miller KM, Clements JM, Lury J, Corkill D, Anthony DC, Adams SE, Gearing AJ. Matrix metalloproteinases, tumor necrosis factor and multiple sclerosis: an overview. J Neuroimmunol. 1997; 72:155-161. [PubMed: 9042108]

Chen YJ, Wei YY, Chen HT, Fong YC, Hsu CJ, Tsai CH, Hsu HC, Liu SH, Tang CH. Osteopontin increases migration and MMP-9 up-regulation via alphavbeta3 integrin, FAK, ERK, and NFkappaB-dependent pathway in human chondrosarcoma cells. J Cell Physiol. 2009; 221:98-108. [PubMed: 19475568]

Chen YW, Nagaraju K, Bakay M, McIntyre O, Rawat R, Shi R, Hoffman EP. Early onset of inflammation and later involvement of TGFbeta in Duchenne muscular dystrophy. Neurology. 2005; 65:826-834. [PubMed: 16093456]

Choi YC, Dalakas MC. Expression of matrix metalloproteinases in the muscle of patients with inflammatory myopathies. Neurology. 2000; 54:65-71. [PubMed: 10636127]

Cohn RD, van Erp C, Habashi JP, Soleimani AA, Klein EC, Lisi MT, Gamradt M, ap Rhys CM, Holm TM, Loeys BL, Ramirez F, Judge DP, Ward CW, Dietz HC. Angiotensin II type 1 receptor blockade attenuates TGF-beta-induced failure of muscle regeneration in multiple myopathic states. Nat Med. 2007; 13:204-210. [PubMed: 17237794]

Culligan KG, Ohlendieck K. Abnormal calcium handling in muscular dystrophy. Basic Appl Myol. 2002; 12:147-157.

Dahiya S, Bhatnagar S, Hindi SM, Jiang C, Paul PK, Kuang S, Kumar A. Elevated levels of active matrix metalloproteinase-9 cause hypertrophy in skeletal muscle of normal and dystrophindeficient mdx mice. Hum Mol Genet. 2011a; 20:4345-4359. [PubMed: 21846793]

Dahiya S, Givvimani S, Bhatnagar S, Qipshidze N, Tyagi SC, Kumar A. Osteopontin-stimulated expression of matrix metalloproteinase- 9 causes cardiomyopathy in the mdx model of Duchenne muscular dystrophy. J Immunol. 2011b; 187:2723-2731. [PubMed: 21810612]

Davies JE, Wang L, Garcia-Oroz L, Cook LJ, Vacher C, O'Donovan DG, Rubinsztein DC. Doxycycline attenuates and delays toxicity of the oculopharyngeal muscular dystrophy mutation in transgenic mice. Nat Med. 2005; 11:672-677. [PubMed: 15864313]

Davies KE, Grounds MD. Modified patient stem cells as prelude to autologous treatment of muscular dystrophy. Cell stem cell. 2007; 1:595-596. [PubMed: 18371397]

De Palma C, Morisi F, Cheli S, Pambianco S, Cappello V, Vezzoli M, Rovere-Querini P, Moggio M, Ripolone M, Francolini M, Sandri M, Clementi E. Autophagy as a new therapeutic target in Duchenne muscular dystrophy. Cell Death Dis. 2012; 3:e418. [PubMed: 23152054]

Delfin DA, Xu Y, Peterson JM, Guttridge DC, Rafael-Fortney JA, Janssen PM. Improvement of cardiac contractile function by peptide-based inhibition of NF-kappaB in the utrophin/dystrophindeficient murine model of muscular dystrophy. J Transl Med. 2011; 9:68. [PubMed: 21586145]

Delfin DA, Zang KE, Schill KE, Patel NT, Janssen PM, Raman SV, Rafael-Fortney JA. Cardiomyopathy in the dystrophin/utrophin-deficient mouse model of severe muscular dystrophy is characterized by dysregulation of matrix metalloproteinases. Neuromuscul Disord. 2012; 22:1006-1014. [PubMed: 22749475]

Denetclaw WF Jr. Hopf FW, Cox GA, Chamberlain JS, Steinhardt RA. Myotubes from transgenic mdx mice expressing full-length dystrophin show normal calcium regulation. Mol Biol Cell. 1994; 5:1159-1167. [PubMed: 7865881]

Desguerre I, Mayer M, Leturcq F, Barbet JP, Gherardi RK, Christov C. Endomysial fibrosis in Duchenne muscular dystrophy: a marker of poor outcome associated with macrophage alternative activation. J Neuropathol Exp Neurol. 2009; 68:762-773. [PubMed: 19535995]

Disatnik MH, Dhawan J, Yu Y, Beal MF, Whirl MM, Franco AA, Rando TA. Evidence of oxidative stress in mdx mouse muscle: studies of the pre-necrotic state. J Neurol Sci. 1998; 161:77-84. [PubMed: 9879685]

Dogra C, Changotra H, Wergedal JE, Kumar A. Regulation of phosphatidylinositol 3-kinase (PI3K)/ Akt and nuclear factor-kappa B signaling pathways in dystrophin-deficient skeletal muscle in response to mechanical stretch. J Cell Physiol. 2006; 208:575-585. [PubMed: 16741926]

Dominov JA, Kravetz AJ, Ardelt M, Kostek CA, Beermann ML, Miller JB. Muscle-specific BCL2 expression ameliorates muscle disease in laminin \{alpha\}2-deficient, but not in dystrophindeficient, mice. Hum Mol Genet. 2005; 14:1029-1040. [PubMed: 15757977] 
Durham WJ, Arbogast S, Gerken E, Li YP, Reid MB. Progressive nuclear factor-kappaB activation resistant to inhibition by contraction and curcumin in mdx mice. Muscle Nerve. 2006; 34:298-303. [PubMed: 16718687]

Emery AE. The muscular dystrophies. Lancet. 2002; 359:687-695. [PubMed: 11879882]

Engvall E, Wewer UM. The new frontier in muscular dystrophy research: booster genes. FASEB J. 2003; 17:1579-1584. [PubMed: 12958164]

Enwere EK, Boudreault L, Holbrook J, Timusk K, Earl N, Lacasse E, Renaud JM, Korneluk RG. Loss of cIAP1 attenuates soleus muscle pathology and improves diaphragm function in mdx mice. Hum Mol Genet. 2013; 22:867-878. [PubMed: 23184147]

Enwere EK, Holbrook J, Lejmi-Mrad R, Vineham J, Timusk K, Sivaraj B, Isaac M, Uehling D, Alawar R, LaCasse E, Korneluk RG. TWEAK and cIAP1 regulate myoblast fusion through the noncanonical NF-kappaB signaling pathway. Sci Signal. 2012; 5:ra75. [PubMed: 23074266]

Evans NP, Misyak SA, Robertson JL, Bassaganya-Riera J, Grange RW. Immune-mediated mechanisms potentially regulate the disease time-course of duchenne muscular dystrophy and provide targets for therapeutic intervention. PM R. 2009; 1:755-768. [PubMed: 19695529]

Finkel RS. Read-through strategies for suppression of nonsense mutations in Duchenne/ Becker muscular dystrophy: aminoglycosides and ataluren (PTC124). J Child Neurol. 2010; 25:11581164. [PubMed: 20519671]

Fong PY, Turner PR, Denetclaw WF, Steinhardt RA. Increased activity of calcium leak channels in myotubes of Duchenne human and mdx mouse origin. Science. 1990; 250:673-676. [PubMed: 2173137]

Franco A Jr. Lansman JB. Calcium entry through stretch-inactivated ion channels in mdx myotubes. Nature. 1990; 344:670-673. [PubMed: 1691450]

Gailly P. New aspects of calcium signaling in skeletal muscle cells: implications in Duchenne muscular dystrophy. Biochim Biophys Acta. 2002; 1600:38-44. [PubMed: 12445457]

Girgenrath M, Beermann ML, Vishnudas VK, Homma S, Miller JB. Pathology is alleviated by doxycycline in a laminin-alpha2-null model of congenital muscular dystrophy. Ann Neurol. 2009; 65:47-56. [PubMed: 19086074]

Girgenrath M, Dominov JA, Kostek CA, Miller JB. Inhibition of apoptosis improves outcome in a model of congenital muscular dystrophy. J Clin Invest. 2004; 114:1635-1639. [PubMed: 15578095]

Goll DE, Thompson VF, Li H, Wei W, Cong J. The calpain system. Physiol Rev. 2003; 83:731-801. [PubMed: 12843408]

Gorospe JR, Tharp M, Demitsu T, Hoffman EP. Dystrophin-deficient myofibers are vulnerable to mast cell granule-induced necrosis. Neuromuscul Disord. 1994a; 4:325-333. [PubMed: 7981589]

Gorospe JR, Tharp MD, Hinckley J, Kornegay JN, Hoffman EP. A role for mast cells in the progression of Duchenne muscular dystrophy? Correlations in dystrophin-deficient humans, dogs, and mice. J Neurol Sci. 1994b; 122:44-56. [PubMed: 8195802]

Gosselin LE, Williams JE, Deering M, Brazeau D, Koury S, Martinez DA. Localization and early time course of TGF-beta 1 mRNA expression in dystrophic muscle. Muscle Nerve. 2004; 30:645-653. [PubMed: 15389721]

Goyenvalle A, Seto JT, Davies KE, Chamberlain J. Therapeutic approaches to muscular dystrophy. Hum Mol Genet. 2011; 20:R69-78. [PubMed: 21436158]

Griggs RC, Moxley RT 3rd, Mendell JR, Fenichel GM, Brooke MH, Pestronk A, Miller JP, Cwik VA, Pandya S, Robison J, et al. Duchenne dystrophy: randomized, controlled trial of prednisone (18 months) and azathioprine (12 months). Neurology. 1993; 43:520-527. [PubMed: 8450994]

Grobet L, Martin LJ, Poncelet D, Pirottin D, Brouwers B, Riquet J, Schoeberlein A, Dunner S, Menissier F, Massabanda J, Fries R, Hanset R, Georges M. A deletion in the bovine myostatin gene causes the double-muscled phenotype in cattle. Nat Genet. 1997; 17:71-74. [PubMed: 9288100]

Grounds MD, Torrisi J. Anti-TNFalpha (Remicade) therapy protects dystrophic skeletal muscle from necrosis. FASEB J. 2004; 18:676-682. [PubMed: 15054089]

Grumati P, Coletto L, Sabatelli P, Cescon M, Angelin A, Bertaggia E, Blaauw B, Urciuolo A, Tiepolo T, Merlini L, Maraldi NM, Bernardi P, Sandri M, Bonaldo P. Autophagy is defective in collagen 
VI muscular dystrophies, and its reactivation rescues myofiber degeneration. Nat Med. 2010; 16:1313-1320. [PubMed: 21037586]

Haslbeck KM, Friess U, Schleicher ED, Bierhaus A, Nawroth PP, Kirchner A, Pauli E, Neundorfer B, Heuss D. The RAGE pathway in inflammatory myopathies and limb girdle muscular dystrophy. Acta Neuropathol. 2005; 110:247-254. [PubMed: 15986224]

Haslett JN, Sanoudou D, Kho AT, Bennett RR, Greenberg SA, Kohane IS, Beggs AH, Kunkel LM. Gene expression comparison of biopsies from Duchenne muscular dystrophy (DMD) and normal skeletal muscle. Proc Natl Acad Sci U S A. 2002; 99:15000-15005. [PubMed: 12415109]

Hauser E, Hoger H, Bittner R, Widhalm K, Herkner K, Lubec G. Oxyradical damage and mitochondrial enzyme activities in the mdx mouse. Neuropediatrics. 1995; 26:260-262. [PubMed: 8552217]

Haycock JW, MacNeil S, Jones P, Harris JB, Mantle D. Oxidative damage to muscle protein in Duchenne muscular dystrophy. Neuroreport. 1996; 8:357-361. [PubMed: 9051810]

Hayden MS, Ghosh S. Signaling to NF-kappaB. Genes Dev. 2004; 18:2195-2224. [PubMed: 15371334]

Hnia K, Gayraud J, Hugon G, Ramonatxo M, De La Porte S, Matecki S, Mornet D. L-arginine decreases inflammation and modulates the nuclear factor-kappaB/matrix metalloproteinase cascade in mdx muscle fibers. Am J Pathol. 2008; 172:1509-1519. [PubMed: 18458097]

Hnia K, Hugon G, Rivier F, Masmoudi A, Mercier J, Mornet D. Modulation of p38 mitogen-activated protein kinase cascade and metalloproteinase activity in diaphragm muscle in response to free radical scavenger administration in dystrophin-deficient Mdx mice. Am J Pathol. 2007; 170:633643. [PubMed: 17255331]

Hodgetts S, Radley H, Davies M, Grounds MD. Reduced necrosis of dystrophic muscle by depletion of host neutrophils, or blocking TNFalpha function with Etanercept in mdx mice. Neuromuscul Disord. 2006; 16:591-602. [PubMed: 16935507]

Hoffman EP, Brown RH Jr. Kunkel LM. Dystrophin: the protein product of the Duchenne muscular dystrophy locus. Cell. 1987; 51:919-928. [PubMed: 3319190]

Hogan PG, Chen L, Nardone J, Rao A. Transcriptional regulation by calcium, calcineurin, and NFAT. Genes Dev. 2003; 17:2205-2232. [PubMed: 12975316]

Hopf FW, Reddy P, Hong J, Steinhardt RA. A capacitative calcium current in cultured skeletal muscle cells is mediated by the calcium-specific leak channel and inhibited by dihydropyridine compounds. J Biol Chem. 1996; 271:22358-22367. [PubMed: 8798397]

Hoyhtya M, Hujanen E, Turpeenniemi-Hujanen T, Thorgeirsson U, Liotta LA, Tryggvason K. Modulation of type-IV collagenase activity and invasive behavior of metastatic human melanoma (A2058) cells in vitro by monoclonal antibodies to type-IV collagenase. Int J Cancer. 1990; 46:282-286. [PubMed: 2166712]

Hu J, Van den Steen PE, Sang QX, Opdenakker G. Matrix metalloproteinase inhibitors as therapy for inflammatory and vascular diseases. Nat Rev Drug Discov. 2007; 6:480-498. [PubMed: 17541420]

Ignotz RA, Massague J. Transforming growth factor-beta stimulates the expression of fibronectin and collagen and their incorporation into the extracellular matrix. J Biol Chem. 1986; 261:4337-4345. [PubMed: 3456347]

Irwin WA, Bergamin N, Sabatelli P, Reggiani C, Megighian A, Merlini L, Braghetta P, Columbaro M, Volpin D, Bressan GM, Bernardi P, Bonaldo P. Mitochondrial dysfunction and apoptosis in myopathic mice with collagen VI deficiency. Nat Genet. 2003; 35:367-371. [PubMed: 14625552]

Javierre BM, Fernandez AF, Richter J, Al-Shahrour F, Martin-Subero JI, Rodriguez-Ubreva J, Berdasco M, Fraga MF, O'Hanlon TP, Rider LG, Jacinto FV, Lopez-Longo FJ, Dopazo J, Forn M, Peinado MA, Carreno L, Sawalha AH, Harley JB, Siebert R, Esteller M, Miller FW, Ballestar E. Changes in the pattern of DNA methylation associate with twin discordance in systemic lupus erythematosus. Genome Res. 2010; 20:170-179. [PubMed: 20028698]

Kar NC, Pearson CM. Catalase, superoxide dismutase, glutathione reductase and thiobarbituric acidreactive products in normal and dystrophic human muscle. Clin Chim Acta. 1979; 94:277-280. [PubMed: 466816] 
Kemaladewi DU, Hoogaars WM, van Heiningen SH, Terlouw S, de Gorter DJ, den Dunnen JT, van Ommen GJ, Aartsma-Rus A, ten Dijke P, t Hoen PA. Dual exon skipping in myostatin and dystrophin for Duchenne muscular dystrophy. BMC Med Genomics. 2011; 4:36. [PubMed: 21507246]

Kherif S, Lafuma C, Dehaupas M, Lachkar S, Fournier JG, Verdiere-Sahuque M, Fardeau M, Alameddine HS. Expression of matrix metalloproteinases 2 and 9 in regenerating skeletal muscle: a study in experimentally injured and mdx muscles. Dev Biol. 1999; 205:158-170. [PubMed: 9882504]

Khurana TS, Davies KE. Pharmacological strategies for muscular dystrophy. Nat Rev Drug Discov. 2003; 2:379-390. [PubMed: 12750741]

Kieseier BC, Schneider C, Clements JM, Gearing AJ, Gold R, Toyka KV, Hartung HP. Expression of specific matrix metalloproteinases in inflammatory myopathies. Brain. 2001; 124:341-351. [PubMed: 11157561]

Kirschner J, Schessl J, Schara U, Reitter B, Stettner GM, Hobbiebrunken E, Wilichowski E, Bernert G, Weiss S, Stehling F, Wiegand G, Muller-Felber W, Thiele S, Grieben U, von der Hagen M, Lutschg J, Schmoor C, Ihorst G, Korinthenberg R. Treatment of Duchenne muscular dystrophy with ciclosporin A: a randomised, double-blind, placebo-controlled multicentre trial. Lancet Neurol. 2010; 9:1053-1059. [PubMed: 20801085]

Kissel JT, Lynn DJ, Rammohan KW, Klein JP, Griggs RC, Moxley RT 3rd, Cwik VA, Brooke MH, Mendell JR. Mononuclear cell analysis of muscle biopsies in prednisoneand azathioprine-treated Duchenne muscular dystrophy. Neurology. 1993; 43:532-536. [PubMed: 8450996]

Koskinen SO, Kjaer M, Mohr T, Sorensen FB, Suuronen T, Takala TE. Type IV collagen and its degradation in paralyzed human muscle: effect of functional electrical stimulation. Muscle Nerve. 2000; 23:580-589. [PubMed: 10716770]

Koskinen SO, Wang W, Ahtikoski AM, Kjaer M, Han XY, Komulainen J, Kovanen V, Takala TE. Acute exercise induced changes in rat skeletal muscle mRNAs and proteins regulating type IV collagen content. Am J Physiol Regul Integr Comp Physiol. 2001; 280:R1292-1300. [PubMed: 11294746]

Kumar A, Bhatnagar S, Kumar A. Matrix metalloproteinase inhibitor batimastat alleviates pathology and improves skeletal muscle function in dystrophin-deficient mdx mice. Am J Pathol. 2010; 177:248-260. [PubMed: 20472898]

Kumar A, Boriek AM. Mechanical stress activates the nuclear factor-kappaB pathway in skeletal muscle fibers: a possible role in Duchenne muscular dystrophy. FASEB J. 2003; 17:386-396. [PubMed: 12631578]

Kumar A, Khandelwal N, Malya R, Reid MB, Boriek AM. Loss of dystrophin causes aberrant mechanotransduction in skeletal muscle fibers. FASEB J. 2004a; 18:102-113. [PubMed: 14718391]

Kumar A, Takada Y, Boriek AM, Aggarwal BB. Nuclear factor-kappaB: its role in health and disease. J Mol Med. 2004b; 82:434-448. [PubMed: 15175863]

Lammerding J, Schulze PC, Takahashi T, Kozlov S, Sullivan T, Kamm RD, Stewart CL, Lee RT. Lamin A/C deficiency causes defective nuclear mechanics and mechanotransduction. J Clin Invest. 2004; 113:370-378. [PubMed: 14755334]

Langen RC, Schols AM, Kelders MC, Wouters EF, Janssen-Heininger YM. Inflammatory cytokines inhibit myogenic differentiation through activation of nuclear factor-kappaB. FASEB J. 2001; 15:1169-1180. [PubMed: 11344085]

Langenbach KJ, Rando TA. Inhibition of dystroglycan binding to laminin disrupts the PI3K/AKT pathway and survival signaling in muscle cells. Muscle Nerve. 2002; 26:644-653. [PubMed: 12402286]

Lawler JM. Exacerbation of pathology by oxidative stress in respiratory and locomotor muscles with Duchenne muscular dystrophy. J Physiol. 2011; 589:2161-2170. [PubMed: 21486793]

Lee SJ, Huynh TV, Lee YS, Sebald SM, Wilcox-Adelman SA, Iwamori N, Lepper C, Matzuk MM, Fan CM. Role of satellite cells versus myofibers in muscle hypertrophy induced by inhibition of the myostatin/activin signaling pathway. Proc Natl Acad Sci U S A. 2012; 109:E2353-2360. [PubMed: 22869749] 
Lee SJ, McPherron AC. Regulation of myostatin activity and muscle growth. Proc Natl Acad Sci U S A. 2001; 98:9306-9311. [PubMed: 11459935]

Li H, Malhotra S, Kumar A. Nuclear factor-kappa B signaling in skeletal muscle atrophy. J Mol Med. 2008; 86:1113-1126. [PubMed: 18574572]

Li H, Mittal A, Makonchuk DY, Bhatnagar S, Kumar A. Matrix Metalloproteinase-9 Inhibition Ameliorates Pathogenesis and Improves Skeletal Muscle Regeneration in Muscular Dystrophy. Hum Mol Genet. 2009; 18:2584-2598. [PubMed: 19401296]

Li Y, Foster W, Deasy BM, Chan Y, Prisk V, Tang Y, Cummins J, Huard J. Transforming growth factor-beta1 induces the differentiation of myogenic cells into fibrotic cells in injured skeletal muscle: a key event in muscle fibrogenesis. Am J Pathol. 2004; 164:1007-1019. [PubMed: 14982854]

Lorts A, Schwanekamp JA, Baudino TA, McNally EM, Molkentin JD. Deletion of periostin reduces muscular dystrophy and fibrosis in mice by modulating the transforming growth factor-beta pathway. Proc Natl Acad Sci U S A. 2012; 109:10978-10983. [PubMed: 22711826]

Lu A, Proto JD, Guo L, Tang Y, Lavasani M, Tilstra JS, Niedernhofer LJ, Wang B, Guttridge DC, Robbins PD, Huard J. NF-kappaB negatively impacts the myogenic potential of muscle-derived stem cells. Mol Ther. 2012; 20:661-668. [PubMed: 22158056]

Lu QL, Yokota T, Takeda S, Garcia L, Muntoni F, Partridge T. The status of exon skipping as a therapeutic approach to duchenne muscular dystrophy. Mol Ther. 2011; 19:9-15. [PubMed: 20978473]

Macaione V, Aguennouz M, Rodolico C, Mazzeo A, Patti A, Cannistraci E, Colantone L, Di Giorgio RM, De Luca G, Vita G. RAGE-NF-kappaB pathway activation in response to oxidative stress in facioscapulohumeral muscular dystrophy. Acta Neurol Scand. 2007; 115:115-121. [PubMed: 17212615]

Mallouk N, Jacquemond V, Allard B. Elevated subsarcolemmal Ca2+ in mdx mouse skeletal muscle fibers detected with Ca2+-activated K+ channels. Proc Natl Acad Sci U S A. 2000; 97:49504955. [PubMed: 10781103]

Mammucari C, Milan G, Romanello V, Masiero E, Rudolf R, Del Piccolo P, Burden SJ, Di Lisi R, Sandri C, Zhao J, Goldberg AL, Schiaffino S, Sandri M. FoxO3 controls autophagy in skeletal muscle in vivo. Cell Metab. 2007; 6:458-471. [PubMed: 18054315]

Mann CJ, Perdiguero E, Kharraz Y, Aguilar S, Pessina P, Serrano AL, Munoz-Canoves P. Aberrant repair and fibrosis development in skeletal muscle. Skelet Muscle. 2011; 1:21. [PubMed: 21798099]

Masiero E, Agatea L, Mammucari C, Blaauw B, Loro E, Komatsu M, Metzger D, Reggiani C, Schiaffino S, Sandri M. Autophagy is required to maintain muscle mass. Cell Metab. 2009; 10:507-515. [PubMed: 19945408]

Matsumura K, Zhong D, Saito F, Arai K, Adachi K, Kawai H, Higuchi I, Nishino I, Shimizu T. Proteolysis of beta-dystroglycan in muscular diseases. Neuromuscul Disord. 2005; 15:336-341. [PubMed: 15833425]

May MJ, D'Acquisto F, Madge LA, Glockner J, Pober JS, Ghosh S. Selective inhibition of NF-kappaB activation by a peptide that blocks the interaction of NEMO with the IkappaB kinase complex. Science. 2000; 289:1550-1554. [PubMed: 10968790]

McCroskery S, Thomas M, Maxwell L, Sharma M, Kambadur R. Myostatin negatively regulates satellite cell activation and self-renewal. J Cell Biol. 2003; 162:1135-1147. [PubMed: 12963705]

McDouall RM, Dunn MJ, Dubowitz V. Nature of the mononuclear infiltrate and the mechanism of muscle damage in juvenile dermatomyositis and Duchenne muscular dystrophy. J Neurol Sci. 1990; 99:199-217. [PubMed: 1982294]

Mechler F, Imre S, Dioszeghy P. Lipid peroxidation and superoxide dismutase activity in muscle and erythrocytes in Duchenne muscular dystrophy. J Neurol Sci. 1984; 63:279-283. [PubMed: 6726273]

Messina S, Altavilla D, Aguennouz M, Seminara P, Minutoli L, Monici MC, Bitto A, Mazzeo A, Marini H, Squadrito F, Vita G. Lipid peroxidation inhibition blunts nuclear factor-kappaB activation, reduces skeletal muscle degeneration, and enhances muscle function in mdx mice. Am J Pathol. 2006a; 168:918-926. [PubMed: 16507907] 
Messina S, Bitto A, Aguennouz M, Minutoli L, Monici MC, Altavilla D, Squadrito F, Vita G. Nuclear factor kappa-B blockade reduces skeletal muscle degeneration and enhances muscle function in Mdx mice. Exp Neurol. 2006b; 198:234-241. [PubMed: 16410003]

Michaluk P, Kolodziej L, Mioduszewska B, Wilczynski GM, Dzwonek J, Jaworski J, Gorecki DC, Ottersen OP, Kaczmarek L. Beta-dystroglycan as a target for MMP-9, in response to enhanced neuronal activity. J Biol Chem. 2007; 282:16036-16041. [PubMed: 17426029]

Millay DP, Goonasekera SA, Sargent MA, Maillet M, Aronow BJ, Molkentin JD. Calcium influx is sufficient to induce muscular dystrophy through a TRPC-dependent mechanism. Proc Natl Acad Sci U S A. 2009; 106:19023-19028. [PubMed: 19864620]

Miller JB, Girgenrath M. The role of apoptosis in neuromuscular diseases and prospects for antiapoptosis therapy. Trends Mol Med. 2006; 12:279-286. [PubMed: 16650805]

Miyazaki D, Nakamura A, Fukushima K, Yoshida K, Takeda S, Ikeda SI. Matrix metalloproteinase-2 ablation in dystrophin-deficient mdx muscle reduces angiogenesis resulting in impaired growth of regenerated muscle fibers. Hum Mol Genet. 20112011 Feb 2028. [Epub ahead of print].

Mizuno Y. Changes in superoxide dismutase, catalase, glutathione peroxidase, and glutathione reductase activities and thiobarbituric acid-reactive products levels in early stages of development in dystrophic chickens. Exp Neurol. 1984; 84:58-73. [PubMed: 6705887]

Molkentin JD, Lu JR, Antos CL, Markham B, Richardson J, Robbins J, Grant SR, Olson EN. A calcineurin-dependent transcriptional pathway for cardiac hypertrophy. Cell. 1998; 93:215-228. [PubMed: 9568714]

Mongini T, Ghigo D, Doriguzzi C, Bussolino F, Pescarmona G, Pollo B, Schiffer D, Bosia A. Free cytoplasmic $\mathrm{Ca}++$ at rest and after cholinergic stimulus is increased in cultured muscle cells from Duchenne muscular dystrophy patients. Neurology. 1988; 38:476-480. [PubMed: 3347352]

Monici MC, Aguennouz M, Mazzeo A, Messina C, Vita G. Activation of nuclear factor-kappaB in inflammatory myopathies and Duchenne muscular dystrophy. Neurology. 2003; 60:993-997. [PubMed: 12654966]

Moylan JS, Reid MB. Oxidative stress, chronic disease, and muscle wasting. Muscle Nerve. 2007; 35:411-429. [PubMed: 17266144]

Muchir A, Pavlidis P, Decostre V, Herron AJ, Arimura T, Bonne G, Worman HJ. Activation of MAPK pathways links LMNA mutations to cardiomyopathy in Emery-Dreifuss muscular dystrophy. J Clin Invest. 2007; 117:1282-1293. [PubMed: 17446932]

Nadarajah VD, van Putten M, Chaouch A, Garrood P, Straub V, Lochmuller H, Ginjaar HB, AartsmaRus AM, van Ommen GJ, den Dunnen JT, t Hoen PA. Serum matrix metalloproteinase-9 (MMP-9) as a biomarker for monitoring disease progression in Duchenne muscular dystrophy (DMD). Neuromuscul Disord. 2011; 21:569-578. [PubMed: 21724396]

Nagy B, Samaha FJ. Membrane defects in Duchenne dystrophy: protease affecting sarcoplasmic reticulum. Ann Neurol. 1986; 20:50-56. [PubMed: 3527039]

Onofre-Oliveira PC, Santos AL, Martins PM, Ayub-Guerrieri D, Vainzof M. Differential expression of genes involved in the degeneration and regeneration pathways in mouse models for muscular dystrophies. Neuromolecular Med. 2012; 14:74-83. [PubMed: 22362587]

Page-McCaw A, Ewald AJ, Werb Z. Matrix metalloproteinases and the regulation of tissue remodelling. Nat Rev Mol Cell Biol. 2007; 8:221-233. [PubMed: 17318226]

Parsons SA, Millay DP, Sargent MA, Naya FJ, McNally EM, Sweeney HL, Molkentin JD. Genetic disruption of calcineurin improves skeletal muscle pathology and cardiac disease in a mouse model of limb-girdle muscular dystrophy. J Biol Chem. 2007; 282:10068-10078. [PubMed: 17289669]

Pauly M, Daussin F, Burelle Y, Li T, Godin R, Fauconnier J, Koechlin-Ramonatxo C, Hugon G, Lacampagne A, Coisy-Quivy M, Liang F, Hussain S, Matecki S, Petrof BJ. AMPK activation stimulates autophagy and ameliorates muscular dystrophy in the mdx mouse diaphragm. Am J Pathol. 2012; 181:583-592. [PubMed: 22683340]

Pearson AM, Young RB. Diseases and disorders of muscle. Adv Food Nutr Res. 1993; 37:339-423. [PubMed: 8398047] 
Pereira JA, Taniguti AP, Matsumura C, Marques MJ, Neto HS. Doxycycline ameliorates the dystrophic phenotype of skeletal and cardiac muscles in mdx mice. Muscle Nerve. 2012; 46:400406. [PubMed: 22907231]

Pescatori M, Broccolini A, Minetti C, Bertini E, Bruno C, D'Amico A, Bernardini C, Mirabella M, Silvestri G, Giglio V, Modoni A, Pedemonte M, Tasca G, Galluzzi G, Mercuri E, Tonali PA, Ricci E. Gene expression profiling in the early phases of DMD: a constant molecular signature characterizes DMD muscle from early postnatal life throughout disease progression. FASEB J. 2007; 21:1210-1226. [PubMed: 17264171]

Peter AK, Crosbie RH. Hypertrophic response of Duchenne and limb-girdle muscular dystrophies is associated with activation of Akt pathway. Exp Cell Res. 2006; 312:2580-2591. [PubMed: 16797529]

Peter AK, Ko CY, Kim MH, Hsu N, Ouchi N, Rhie S, Izumiya Y, Zeng L, Walsh K, Crosbie RH. Myogenic Akt signaling upregulates the utrophin-glycoprotein complex and promotes sarcolemma stability in muscular dystrophy. Hum Mol Genet. 2009; 18:318-327. [PubMed: 18986978]

Peterson JM, Kline W, Canan BD, Ricca DJ, Kaspar B, Delfin DA, DiRienzo K, Clemens PR, Robbins PD, Baldwin AS, Flood P, Kaumaya P, Freitas M, Kornegay JN, Mendell JR, Rafael-Fortney JA, Guttridge DC, Janssen PM. Peptide-based inhibition of NF-kappaB rescues diaphragm muscle contractile dysfunction in a murine model of Duchenne muscular dystrophy. Mol Med. 2011; 17:508-515. [PubMed: 21267511]

Petrof BJ, Shrager JB, Stedman HH, Kelly AM, Sweeney HL. Dystrophin protects the sarcolemma from stresses developed during muscle contraction. Proc Natl Acad Sci U S A. 1993; 90:3710 3714. [PubMed: 8475120]

Porter JD, Guo W, Merriam AP, Khanna S, Cheng G, Zhou X, Andrade FH, Richmonds C, Kaminski HJ. Persistent over-expression of specific CC class chemokines correlates with macrophage and T-cell recruitment in mdx skeletal muscle. Neuromuscul Disord. 2003a; 13:223-235. [PubMed: 12609504]

Porter JD, Khanna S, Kaminski HJ, Rao JS, Merriam AP, Richmonds CR, Leahy P, Li J, Andrade FH. Extraocular muscle is defined by a fundamentally distinct gene expression profile. Proc Natl Acad Sci U S A. 2001; 98:12062-12067. [PubMed: 11572940]

Porter JD, Khanna S, Kaminski HJ, Rao JS, Merriam AP, Richmonds CR, Leahy P, Li J, Guo W, Andrade FH. A chronic inflammatory response dominates the skeletal muscle molecular signature in dystrophin-deficient mdx mice. Hum Mol Genet. 2002; 11:263-272. [PubMed: 11823445]

Porter JD, Merriam AP, Leahy P, Gong B, Feuerman J, Cheng G, Khanna S. Temporal gene expression profiling of dystrophin-deficient $(\mathrm{mdx})$ mouse diaphragm identifies conserved and muscle group-specific mechanisms in the pathogenesis of muscular dystrophy. Hum Mol Genet. 2004; 13:257-269. [PubMed: 14681298]

Porter JD, Merriam AP, Leahy P, Gong B, Khanna S. Dissection of temporal gene expression signatures of affected and spared muscle groups in dystrophin-deficient (mdx) mice. Hum Mol Genet. 2003b; 12:1813-1821. [PubMed: 12874102]

Prins KW, Humston JL, Mehta A, Tate V, Ralston E, Ervasti JM. Dystrophin is a microtubuleassociated protein. J Cell Biol. 2009; 186:363-369. [PubMed: 19651889]

Raffetto JD, Khalil RA. Matrix metalloproteinases and their inhibitors in vascular remodeling and vascular disease. Biochem Pharmacol. 2008; 75:346-359. [PubMed: 17678629]

Rando TA. The dystrophin-glycoprotein complex, cellular signaling, and the regulation of cell survival in the muscular dystrophies. Muscle Nerve. 2001; 24:1575-1594. [PubMed: 11745966]

Rando TA. Oxidative stress and the pathogenesis of muscular dystrophies. Am J Phys Med Rehabil. 2002; 81:S175-186. [PubMed: 12409822]

Rando TA, Disatnik MH, Yu Y, Franco A. Muscle cells from mdx mice have an increased susceptibility to oxidative stress. Neuromuscul Disord. 1998; 8:14-21. [PubMed: 9565986]

Rangaswami H, Bulbule A, Kundu GC. Nuclear factor-inducing kinase plays a crucial role in osteopontin-induced MAPK/IkappaBalpha kinase-dependent nuclear factor kappaB-mediated 
promatrix metalloproteinase-9 activation. J Biol Chem. 2004; 279:38921-38935. [PubMed: 15247285]

Razani B, Reichardt AD, Cheng G. Non-canonical NF-kappaB signaling activation and regulation: principles and perspectives. Immunol Rev. 2011; 244:44-54. [PubMed: 22017430]

Reay DP, Yang M, Watchko JF, Daood M, O'Day TL, Rehman KK, Guttridge DC, Robbins PD, Clemens PR. Systemic delivery of NEMO binding domain/IKKgamma inhibitory peptide to young mdx mice improves dystrophic skeletal muscle histopathology. Neurobiol Dis. 2011; 43:598-608. [PubMed: 21624467]

Richard I, Roudaut C, Marchand S, Baghdiguian S, Herasse M, Stockholm D, Ono Y, Suel L, Bourg N, Sorimachi H, Lefranc G, Fardeau M, Sebille A, Beckmann JS. Loss of calpain 3 proteolytic activity leads to muscular dystrophy and to apoptosis-associated IkappaBalpha/nuclear factor kappaB pathway perturbation in mice. J Cell Biol. 2000; 151:1583-1590. [PubMed: 11134085]

Roma J, Munell F, Fargas A, Roig M. Evolution of pathological changes in the gastrocnemius of the mdx mice correlate with utrophin and beta-dystroglycan expression. Acta Neuropathol. 2004; 108:443-452. [PubMed: 15365724]

Sandri M. Signaling in muscle atrophy and hypertrophy. Physiology (Bethesda). 2008; 23:160-170. [PubMed: 18556469]

Sandri M. Autophagy in skeletal muscle. FEBS Lett. 2010; 584:1411-1416. [PubMed: 20132819]

Sandri M, Sandri C, Gilbert A, Skurk C, Calabria E, Picard A, Walsh K, Schiaffino S, Lecker SH, Goldberg AL. Foxo transcription factors induce the atrophy-related ubiquitin ligase atrogin-1 and cause skeletal muscle atrophy. Cell. 2004; 117:399-412. [PubMed: 15109499]

Schoser BG, Blottner D, Stuerenburg HJ. Matrix metalloproteinases in inflammatory myopathies: enhanced immunoreactivity near atrophic myofibers. Acta Neurol Scand. 2002; 105:309-313. [PubMed: 11939944]

Sharma R, Anker SD. Cytokines, apoptosis and cachexia: the potential for TNF antagonism. Int J Cardiol. 2002; 85:161-171. [PubMed: 12163221]

Siegel AL, Bledsoe C, Lavin J, Gatti F, Berge J, Millman G, Turin E, Winders WT, Rutter J, Palmeiri B, Carlson CG. Treatment with inhibitors of the NF-kappaB pathway improves whole body tension development in the mdx mouse. Neuromuscul Disord. 2009; 19:131-139. [PubMed: 19054675]

Spencer MJ, Mellgren RL. Overexpression of a calpastatin transgene in mdx muscle reduces dystrophic pathology. Hum Mol Genet. 2002; 11:2645-2655. [PubMed: 12354790]

Spencer MJ, Montecino-Rodriguez E, Dorshkind K, Tidball JG. Helper (CD4(+)) and cytotoxic (CD8(+)) T cells promote the pathology of dystrophin-deficient muscle. Clin Immunol. 2001; 98:235-243. [PubMed: 11161980]

Spencer MJ, Tidball JG. Do immune cells promote the pathology of dystrophin-deficient myopathies? Neuromuscul Disord. 2001; 11:556-564. [PubMed: 11525885]

Spencer MJ, Walsh CM, Dorshkind KA, Rodriguez EM, Tidball JG. Myonuclear apoptosis in dystrophic mdx muscle occurs by perforin-mediated cytotoxicity. J Clin Invest. 1997; 99:27452751. [PubMed: 9169505]

Spurney CF, Knoblach S, Pistilli EE, Nagaraju K, Martin GR, Hoffman EP. Dystrophin-deficient cardiomyopathy in mouse: expression of Nox4 and Lox are associated with fibrosis and altered functional parameters in the heart. Neuromuscul Disord. 2008; 18:371-381. [PubMed: 18440230]

Stedman HH, Sweeney HL, Shrager JB, Maguire HC, Panettieri RA, Petrof B, Narusawa M, Leferovich JM, Sladky JT, Kelly AM. The mdx mouse diaphragm reproduces the degenerative changes of Duchenne muscular dystrophy. Nature. 1991; 352:536-539. [PubMed: 1865908]

Stupka N, Gregorevic P, Plant DR, Lynch GS. The calcineurin signal transduction pathway is essential for successful muscle regeneration in mdx dystrophic mice. Acta Neuropathol. 2004; 107:299310. [PubMed: 14727129]

Stupka N, Michell BJ, Kemp BE, Lynch GS. Differential calcineurin signalling activity and regeneration efficacy in diaphragm and limb muscles of dystrophic mdx mice. Neuromuscul Disord. 2006; 16:337-346. [PubMed: 16621557] 
Stupka N, Schertzer JD, Bassel-Duby R, Olson EN, Lynch GS. Stimulation of calcineurin Aalpha activity attenuates muscle pathophysiology in mdx dystrophic mice. Am J Physiol Regul Integr Comp Physiol. 2008; 294:R983-992. [PubMed: 18199592]

Sundaram JS, Rao VM, Meena AK, Anandaraj MP. Decreased calcineurin activity in circulation of Duchenne muscular dystrophy. Clin Biochem. 2007; 40:443-446. [PubMed: 17328882]

Tang Y, Reay DP, Salay MN, Mi MY, Clemens PR, Guttridge DC, Robbins PD, Huard J, Wang B. Inhibition of the IKK/NF-kappaB pathway by AAV gene transfer improves muscle regeneration in older mdx mice. Gene Ther. 2010; 17:1476-1483. [PubMed: 20720575]

Terrill JR, Radley-Crabb HG, Iwasaki T, Lemckert FA, Arthur PG, Grounds MD. Oxidative stress and pathology in muscular dystrophies: focus on protein thiol oxidation and dysferlinopathies. FEBS J. 2013 (2013 Jan 19, Epub ahead of print).

Tews DS. Muscle-fiber apoptosis in neuromuscular diseases. Muscle Nerve. 2005; 32:443-458. [PubMed: 15937870]

Thomas M, Langley B, Berry C, Sharma M, Kirk S, Bass J, Kambadur R. Myostatin, a negative regulator of muscle growth, functions by inhibiting myoblast proliferation. J Biol Chem. 2000; 275:40235-40243. [PubMed: 10976104]

Tidball JG. Inflammatory cell response to acute muscle injury. Med Sci Sports Exerc. 1995; 27:10221032. [PubMed: 7564969]

Tidball JG. Inflammatory processes in muscle injury and repair. Am J Physiol Regul Integr Comp Physiol. 2005; 288:R345-353. [PubMed: 15637171]

Tidball JG, Albrecht DE, Lokensgard BE, Spencer MJ. Apoptosis precedes necrosis of dystrophindeficient muscle. J Cell Sci. 1995; 108:2197-2204. [PubMed: 7673339]

Tidball JG, Villalta SA. Regulatory interactions between muscle and the immune system during muscle regeneration. Am J Physiol Regul Integr Comp Physiol. 2010; 298:R1173-1187. [PubMed: 20219869]

Tidball JG, Wehling-Henricks M. Evolving therapeutic strategies for Duchenne muscular dystrophy: targeting downstream events. Pediatr Res. 2004; 56:831-841. [PubMed: 15531741]

Tidball JG, Wehling-Henricks M. The role of free radicals in the pathophysiology of muscular dystrophy. J Appl Physiol. 2007; 102:1677-1686. [PubMed: 17095633]

Turgeman T, Hagai Y, Huebner K, Jassal DS, Anderson JE, Genin O, Nagler A, Halevy O, Pines M. Prevention of muscle fibrosis and improvement in muscle performance in the mdx mouse by halofuginone. Neuromuscul Disord. 2008; 18:857-868. [PubMed: 18672370]

Turner PR, Westwood T, Regen CM, Steinhardt RA. Increased protein degradation results from elevated free calcium levels found in muscle from mdx mice. Nature. 1988; 335:735-738. [PubMed: 3173492]

Turpeenniemi-Hujanen T, Thorgeirsson UP, Hart IR, Grant SS, Liotta LA. Expression of collagenase IV (basement membrane collagenase) activity in murine tumor cell hybrids that differ in metastatic potential. J Natl Cancer Inst. 1985; 75:99-103. [PubMed: 2989606]

Vallabhapurapu S, Matsuzawa A, Zhang W, Tseng PH, Keats JJ, Wang H, Vignali DA, Bergsagel PL, Karin M. Nonredundant and complementary functions of TRAF2 and TRAF3 in a ubiquitination cascade that activates NIK-dependent alternative NF-kappaB signaling. Nat Immunol. 2008; 9:1364-1370. [PubMed: 18997792]

Varfolomeev E, Blankenship JW, Wayson SM, Fedorova AV, Kayagaki N, Garg P, Zobel K, Dynek JN, Elliott LO, Wallweber HJ, Flygare JA, Fairbrother WJ, Deshayes K, Dixit VM, Vucic D. IAP antagonists induce autoubiquitination of c-IAPs, NF-kappaB activation, and TNFalphadependent apoptosis. Cell. 2007; 131:669-681. [PubMed: 18022362]

Vetrone SA, Montecino-Rodriguez E, Kudryashova E, Kramerova I, Hoffman EP, Liu SD, Miceli MC, Spencer MJ. Osteopontin promotes fibrosis in dystrophic mouse muscle by modulating immune cell subsets and intramuscular TGF-beta. J Clin Invest. 2009; 119:1583-1594. [PubMed: 19451692]

Vidal B, Serrano AL, Tjwa M, Suelves M, Ardite E, De Mori R, Baeza-Raja B, Martinez de Lagran M, Lafuste P, Ruiz-Bonilla V, Jardi M, Gherardi R, Christov C, Dierssen M, Carmeliet P, Degen JL, Dewerchin M, Munoz-Canoves P. Fibrinogen drives dystrophic muscle fibrosis via a TGFbeta/ 
alternative macrophage activation pathway. Gene Dev. 2008; 22:1747-1752. [PubMed: 18593877]

Villalta SA, Deng B, Rinaldi C, Wehling-Henricks M, Tidball JG. IFN-gamma promotes muscle damage in the mdx mouse model of Duchenne muscular dystrophy by suppressing M2 macrophage activation and inhibiting muscle cell proliferation. J Immunol. 2011a; 187:5419 5428. [PubMed: 22013114]

Villalta SA, Nguyen HX, Deng B, Gotoh T, Tidball JG. Shifts in macrophage phenotypes and macrophage competition for arginine metabolism affect the severity of muscle pathology in muscular dystrophy. Hum Mol Genet. 2009; 18:482-496. [PubMed: 18996917]

Villalta SA, Rinaldi C, Deng B, Liu G, Fedor B, Tidball JG. Interleukin-10 reduces the pathology of mdx muscular dystrophy by deactivating M1 macrophages and modulating macrophage phenotype. Hum Mol Genet. 2011b; 20:790-805. [PubMed: 21118895]

$\mathrm{Vu}$ TH, Werb Z. Matrix metalloproteinases: effectors of development and normal physiology. Genes Dev. 2000; 14:2123-2133. [PubMed: 10970876]

Wagner KR, McPherron AC, Winik N, Lee SJ. Loss of myostatin attenuates severity of muscular dystrophy in mdx mice. Ann Neurol. 2002; 52:832-836. [PubMed: 12447939]

Wang KX, Denhardt DT. Osteopontin: role in immune regulation and stress responses. Cytokine Growth Factor Rev. 2008; 19:333-345. [PubMed: 18952487]

Wang X, Weisleder N, Collet C, Zhou J, Chu Y, Hirata Y, Zhao X, Pan Z, Brotto M, Cheng H, Ma J. Uncontrolled calcium sparks act as a dystrophic signal for mammalian skeletal muscle. Nat Cell Biol. 2005; 7:525-530. [PubMed: 15834406]

Waubant E, Goodkin DE, Gee L, Bacchetti P, Sloan R, Stewart T, Andersson PB, Stabler G, Miller K. Serum MMP-9 and TIMP-1 levels are related to MRI activity in relapsing multiple sclerosis. Neurology. 1999; 53:1397-1401. [PubMed: 10534241]

Wehling-Henricks M, Lee JJ, Tidball JG. Prednisolone decreases cellular adhesion molecules required for inflammatory cell infiltration in dystrophin-deficient skeletal muscle. Neuromuscul Disord. 2004; 14:483-490. [PubMed: 15336689]

Wehling M, Spencer MJ, Tidball JG. A nitric oxide synthase transgene ameliorates muscular dystrophy in mdx mice. J Cell Biol. 2001; 155:123-131. [PubMed: 11581289]

Whitehead NP, Pham C, Gervasio OL, Allen DG. N-Acetylcysteine ameliorates skeletal muscle pathophysiology in mdx mice. J Physiol. 2008; 586:2003-2014. [PubMed: 18258657]

Whitehead NP, Yeung EW, Froehner SC, Allen DG. Skeletal muscle NADPH oxidase is increased and triggers stretch-induced damage in the mdx mouse. PloS one. 2010; 5:e15354. [PubMed: 21187957]

Williams DA, Head SI, Bakker AJ, Stephenson DG. Resting calcium concentrations in isolated skeletal muscle fibres of dystrophic mice. J Physiol. 1990; 428:243-256. [PubMed: 2231412]

Williams IA, Allen DG. The role of reactive oxygen species in the hearts of dystrophin-deficient mdx mice. Am J Physiol Heart Circ Physiol. 2007; 293:H1969-1977. [PubMed: 17573457]

Yamazaki M, Minota S, Sakurai H, Miyazono K, Yamada A, Kanazawa I, Kawai M. Expression of transforming growth factor-beta 1 and its relation to endomysial fibrosis in progressive muscular dystrophy. Am J Pathol. 1994; 144:221-226. [PubMed: 8311110]

Yang Q, Tang Y, Imbrogno K, Lu A, Proto JD, Chen A, Guo F, Fu FH, Huard J, Wang B. AAV-based shRNA silencing of NF-kappaB ameliorates muscle pathologies in mdx mice. Gene Ther. 2012; 19:1196-1204. [PubMed: 22278411]

Zarnegar BJ, Wang Y, Mahoney DJ, Dempsey PW, Cheung HH, He J, Shiba T, Yang X, Yeh WC, Mak TW, Korneluk RG, Cheng G. Noncanonical NF-kappaB activation requires coordinated assembly of a regulatory complex of the adaptors cIAP1, cIAP2, TRAF2 and TRAF3 and the kinase NIK. Nat Immunol. 2008; 9:1371-1378. [PubMed: 18997794]

Zhao J, Brault JJ, Schild A, Cao P, Sandri M, Schiaffino S, Lecker SH, Goldberg AL. FoxO3 coordinately activates protein degradation by the autophagic/lysosomal and proteasomal pathways in atrophying muscle cells. Cell Metab. 2007; 6:472-483. [PubMed: 18054316]

Zhong D, Saito F, Saito Y, Nakamura A, Shimizu T, Matsumura K. Characterization of the protease activity that cleaves the extracellular domain of beta-dystroglycan. Biochem Biophys Res Commun. 2006; 345:867-871. [PubMed: 16701552] 


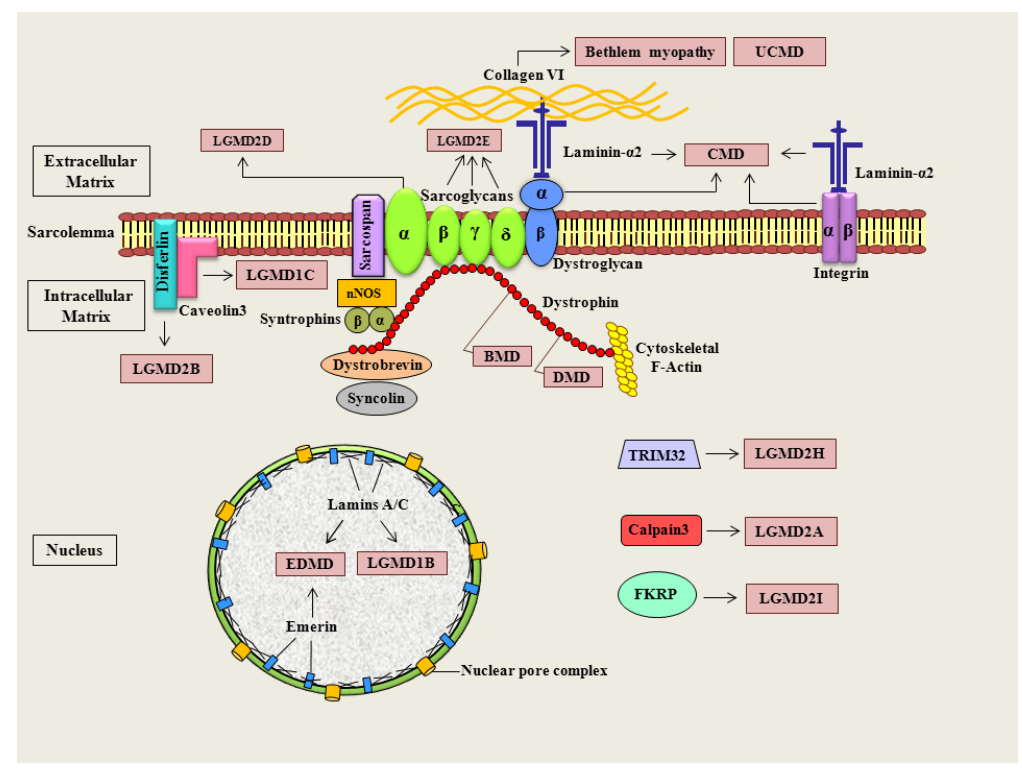

FIGURE 1. Genetic basis of muscular dystrophy

Schematic representation of various proteins and associated muscular dystrophy caused by their loss is presented. BMD, Baker's muscular dystrophy; CMD, Congenital muscular dystrophy; DMD, Duchenne muscular dystrophy; EDMD, Emery-dreifuss muscular dystrophy; FKRP, Fukutin-related protein; LGMD, limb girdle muscular dystrophy; nNOS, neuronal nitric oxide synthase; TRIM, Tripartite motif proteins; UCMD, Ullrich congenital muscular dystrophy. 


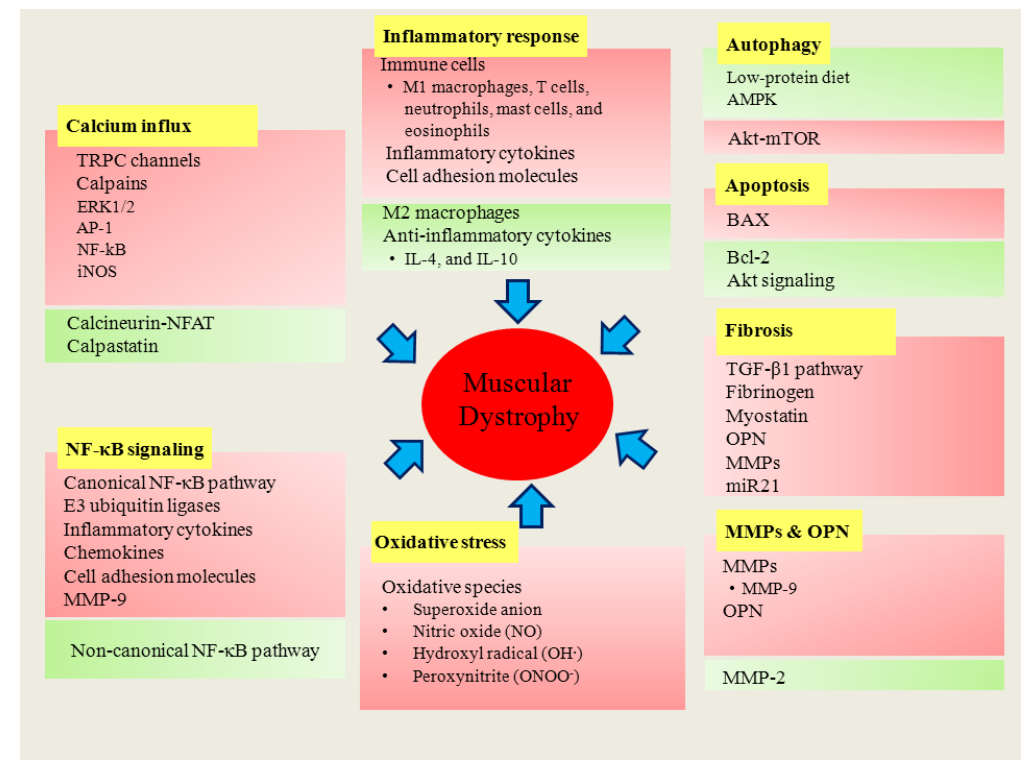

FIGURE 2. Mechanisms of muscle wasting in muscular dystrophy

Major molecular processes (in yellow boxes) involved in pathogenesis of muscle dystrophy especially DMD. Activators or mediators of pathological response of these processed has been depicted in red boxes. Some components (in green boxes) of these pathways improve dystrophic phenotype in muscular dystrophy. 